\title{
Therapeutic Potential of Nucleic Acids when Combined with Extracellular Vesicles
}

\author{
Brian Jurgielewicz ${ }^{1,2}$, Steven Stice ${ }^{1,2,3}$, Yao Yao ${ }^{1,2, *}$ \\ ${ }^{1}$ Regenerative Bioscience Center, University of Georgia, Athens, GA 30602, USA \\ ${ }^{2}$ Department of Animal and Dairy Science, College of Agricultural and Environmental Sciences, University of \\ Georgia, Athens, GA 30602, USA \\ ${ }^{3}$ ArunA Bio, Athens, GA 30602, USA
}

[Received April 14, 2021; Revised July 4, 2021; Accepted July 8, 2021]

\begin{abstract}
Extracellular vesicles (EVs), endogenous nanocarriers of proteins, lipids, and genetic material, have been harnessed as intrinsic delivery vectors for nucleic acid therapies. EVs are nanosized lipid bilayer bound vesicles released from most cell types responsible for delivery of functional biologic material to mediate intercellular communication and to modulate recipient cell phenotypes. Due to their innate biological role and composition, EVs possess several advantages as delivery vectors for nucleic acid based therapies including low immunogenicity and toxicity, high bioavailability, and ability to be engineered to enhance targeting to specific recipient cells in vivo. In this review, the current understanding of the biological role of EVs as well as the advancements in loading EVs to deliver nucleic acid therapies are summarized. We discuss the current methods and associated challenges in loading EVs and the prospects of utilizing the inherent characteristics of EVs as a delivery vector of nucleic acid therapies for genetic disorders.
\end{abstract}

Key words: Extracellular vesicles, nucleic acid delivery, exosome, drug delivery, loading

\section{INTRODUCTION}

Nucleic acid-based therapeutics, small interfering RNA (siRNA), microRNA (miRNA), double stranded DNA (dsDNA) and antisense oligonucleotides (ASOs) are promising disease altering modalities because they target disease causing genes in a sequence specific manner. The specificity of these therapies is a targeted approach for treatment of various diseases, including hereditary amyloidogenic transthyretin amyloidosis, spinal muscular atrophy, Duchenne's Muscular Dystrophy Disease, amyotrophic lateral sclerosis, among others [1-3].
Nucleic acid modalities, siRNA, miRNA or inhibitory ASOs, plasmid DNA, mRNA, small activating RNA, splicing modulatory ASOs, and CRISPR sgRNA, can downregulate, augmented or correct gene expression. [1, $2,4]$. However, these promising therapeutics are severely limited due to inefficient biodistribution and susceptibility to breakdown, creating a need for the development of safe and efficient delivery vectors [5-9]. In this review we focus on EV loading and mediated delivery of siRNA, ASO, and miRNA (Fig. 1) (See more reviews on loading of alternative cargoes into EVs in [10-14]).

*Correspondence should be addressed to: Dr. Yao Yao, Regenerative Bioscience Center, University of Georgia, Athens, GA 30602, USA. Email.Yao.Yao@uga.edu.

Copyright: () 2021 Jurgielewicz B et al. This is an open-access article distributed under the terms of the Creative Commons Attribution License, which permits unrestricted use, distribution, and reproduction in any medium, provided the original author and source are credited. 


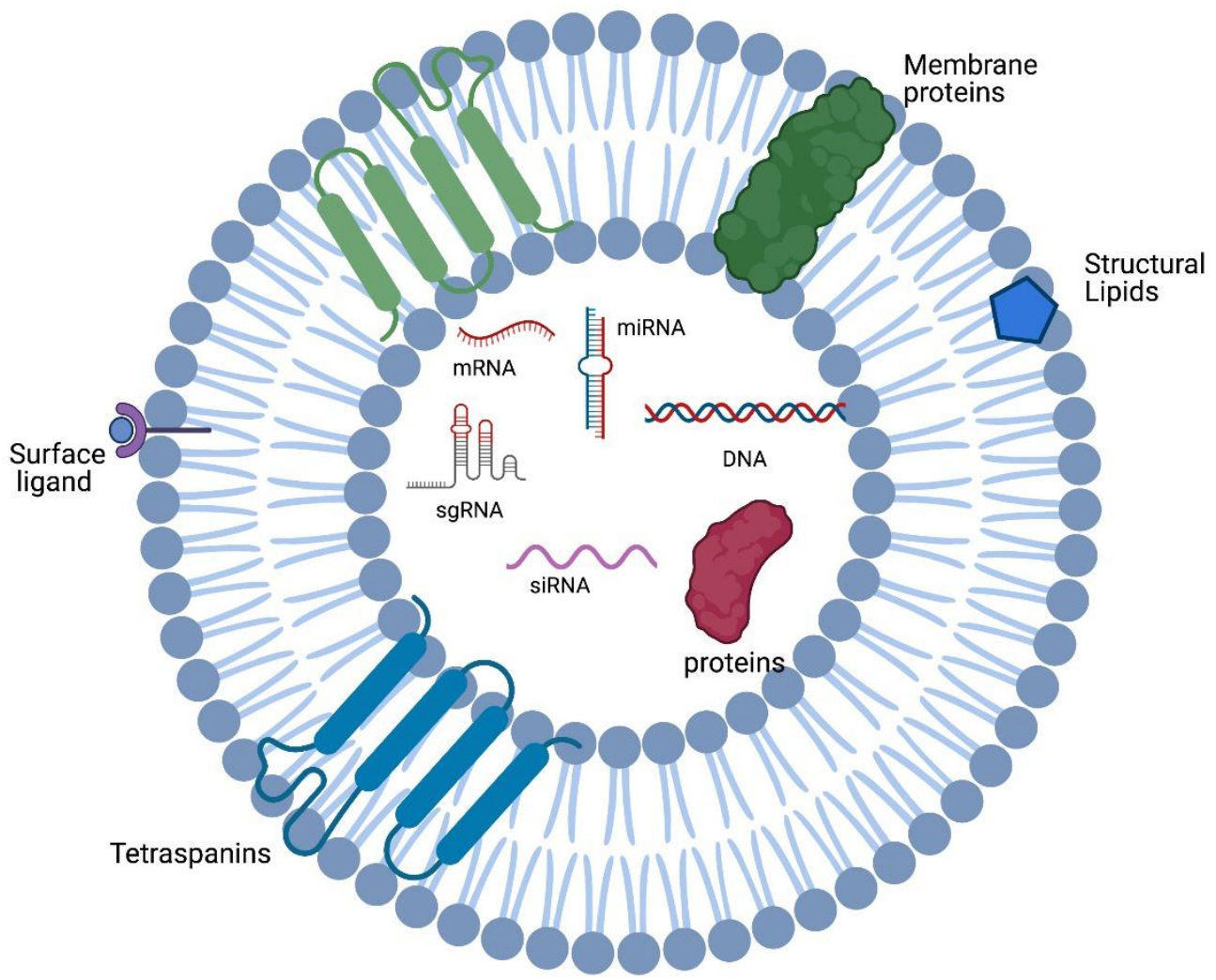

Figure 1. Diagram of therapeutic cargo inside of EVs. EVs are lipid bilayer bound vesicles that can be loaded with therapeutic cargo. Therapeutic cargo includes but not limited to siRNA, ASO, and other nucleic acid therapeutics. The EV membrane contains common tetraspanin markers and other membrane proteins, integrins, and cholesterol.

RNA interference (RNAi), siRNA and miRNA, knocks down target gene expression by binding to specific mRNA for 1) degradation or 2) repression $[1,2,4,15,16]$. siRNAs, 21-23 base pair double stranded oligonucleotides, bind to target mRNA via Watson and Crick pairings and guide the Argonaute 2 protein responsible for mRNA cleavage and inhibition of translation $[17,18]$. Similarly, miRNAs are small noncoding RNAs of approximately 19-25 nucleotides derived from short stem-loop RNAs. Physiologically, miRNAs interact with the 3'UTR of target mRNAs and suppress expression by induction of translation repression and mRNA deadenylation or decapping $[1,4,19,20]$. ASOs are synthetic single stranded 'DNA-like' oligonucleotides ranging between 8-50 base pairs that bind to specific RNA sequences [21]. In a non-RNAi dependent pathway, antisense oligonucleotides, act on target mRNA by three major, yet distinct mechanisms, 1) splicing alteration 2) target degradation and 3) translational arrest [9, 16, 2123]. ASOs can be synthesized to target 5' or 3' splice junction and exonic/intronic splicing enhancer/silencer sites[24], thus skipping or including exons to restore mRNA reading frames, or introduce an out-of-frame deletion $[9,25]$. Secondly, target degradation occurs by the recruitment of RNase $\mathrm{H}$, a ubiquitous enzyme that identifies DNA: RNA hybrid complexes and cleaves the RNA [26]. (For a more detailed overview please refer to $[9,27]$ (See Table 1).

Nucleic acid therapies are limited by systemic instability and poor delivery to targeted cells $[6,7,9]$. Thus, due to their innate biological roles in intercellular communication, EVs have been engineered as delivery vectors. In the preclinical setting, EVs have been employed to deliver siRNA, miRNA, and ASOs to targeted disease inducing genes including BACE1 for Alzheimer's, Htt for Huntington's Disease, and various oncogenic targets [28-31]. Despite this, there remains a divergence between preclinical and clinical success in utilizing EVs as a delivery vector. In this review, we

1) Examine the current delivery strategies of gene therapies.

2) Discuss the biological framework of extracellular vesicles.

3) Assess the loading procedures of gene therapies into or onto extracellular vesicles.

4) Consider the current opportunities and future potential of extracellular vesicle-based gene therapy delivery. 
Table 1. An overview of nucleic acid-based therapies including their function, composition, and example disease targets.

\begin{tabular}{|llll|}
\hline & Function & Composition & Disease Targets \\
\hline RNA Interference: & & & \\
\hline Small Interfering RNA & $\begin{array}{l}\text { 1) Cleave mRNA 2) Inhibit } \\
\text { translation via RISC }\end{array}$ & $\begin{array}{l}\text { 20-27 base pair double } \\
\text { stranded oligonucleotides }\end{array}$ & hATTR, AHP \\
\hline MicroRNA & $\begin{array}{l}\text { Induce translation repression via } \\
\text { mRNA deadenylation or decapping }\end{array}$ & $\begin{array}{l}19-25 \text { nucleotides in } \\
\text { length derived from short } \\
\text { stem-loop RNA }\end{array}$ & Cancer, Hepatitis \\
\hline Non-RNA Interference: & & & \\
\hline $\begin{array}{l}\text { Antisense Oligonucleotide } \\
\text { - Splicing }\end{array}$ & $\begin{array}{l}\text { 1) Restore mRNA reading frames. } \\
\text { 2) Promote inclusion of skipped } \\
\text { exons }\end{array}$ & $\begin{array}{l}8-50 \text { base pair single } \\
\text { stranded oligonucleotides }\end{array}$ & $\begin{array}{l}\text { Spinal Muscular } \\
\text { Atrophy, } \\
\text { 3) introduce an out-of-frame deletion } \\
\text { Muchne's }\end{array}$ \\
\hline $\begin{array}{l}\text { Antisense Oligonucleotide } \\
\text { - Degradation }\end{array}$ & $\begin{array}{l}\text { Recruit Endonulcease breakdown due } \\
\text { to DNA:RNA complex formation }\end{array}$ & $\begin{array}{l}8-50 \text { base pair single } \\
\text { stranded oligonucleotides }\end{array}$ & $\begin{array}{l}\text { Cancer } \\
\text { Dystrophy }\end{array}$ \\
\hline
\end{tabular}

\section{CURRENT DELIVERY STRATEGIES OF NUCLEIC ACID THERAPIES}

An efficient and safe delivery system is integral to the development and large-scale utility of siRNAs, ASOs, and miRNAs. After systematic administration and entry into circulation, nucleases degrade nucleic acids into fragments preventing the accumulation of the therapeutic in the intended tissue $[1,6]$. An ideal vector must be safe with low toxicity and immunogenicity, protect the therapeutic cargo from external breakdown, and to efficiently target the specific tissue or cell population of interests $[6,20,32]$. Specifically, for systemic administration of siRNAs, ASOs, and miRNAs, an optimal delivery vehicle must provide stability against serum nucleases, evade the immune system, prevent immediate renal clearance, exit the vasculature, enter the correct target cells, and lastly escape the endolysosomal system [1, 2, 33, 34]. Commonly used delivery approaches can be classified into two categories 1) modification of the gene therapy itself or 2) use of a delivery vector $[1]$.

\section{1 chemical modifications of nucleic acids}

Several chemical modifications have advanced systemic utility of nucleic acids to improve stability, decrease immunoreactivity, increase concentration, and increase cellular uptake. The most common modifications include a substitution of the 2'-OH with a 2'-O-methyl (2'$\mathrm{OMe})$ or $2^{\prime}$-methoxyethyl (2'-MOE) group or the substitution of certain nucleotides with locked nucleic acid (LNA), unlocked nucleic acid (UNA) or glycol nucleic acid (GNA) [5, 35]. The backbone is typically engineered as a phosphorothioate (PS) backbone to improve stability in circulation and to enhance binding with blood proteins to decrease renal clearance [36, 37]. Several disadvantages include significant toxicities associated with the protein binding capabilities of PS oligonucleotides [38]. Similarly, conjugation with small molecules like cholesterol, peptides, polymers, and others has shown early delivery enhancement, in vivo. Conjugation of nucleic acids with cholesterol or alphatocopherol alters the hydrophobicity and solubility of the molecule, but may decrease the therapeutic efficacy [39]. Cell penetrating peptides (CPPs), 30 amino acid chains of arginine and lysine, have been tagged to siRNA and ASOs [34]. CPPs have high efficacy on anionic cell membranes and potential lysosome escape with an additional hemagglutinin molecule. However, CPPs may elevate cytotoxicity and immunogenicity and the effectiveness may be weakened depending on the nucleic acid cargoes $[34,40]$. Other advanced conjugate systems include dynamic polyconjugates and GalNAC conjugates are promising for delivery, but are limited to liver localization [41], though further work is warranted to alter the tropism. Overall, these modifications provide advancements in therapeutic utility, but challenges hinder wide range applications making delivery vectors a more viable option. For further review of chemical modifications refer to [42-44].

\subsection{Viral vectors}

Viral vectors, specifically adeno-associated virus (AAV) vectors, non-enveloped viruses engineered to deliver nucleic acids, are the most actively investigated gene therapy delivery vectors [45]. AAVs consist of a protein 
shell surrounding and protecting a small single stranded DNA molecules [45]. Viral vectors are advantageous due to their relatively high efficiency of gene transfer, vector tropism to targeted tissue, and ability to provide long term therapy when applicable [20, 32]. Glybera, an AAV1 based vector to treat lipoprotein lipase deficiency gained European approval in 2012. Further in 2017, Luxterna, an AAV2 vector directly injected into the eye expressing retinal pigment epithelium specific $65 \mathrm{kDa}$ protein, was approved by the Food and Drug Administration (FDA). Most recently, Zolgensma, an AAV9 carrying survival motor neuron 1 was approved by the FDA for children with spinal muscular atrophy type 1 [45]. Other nucleotide clinical trial stage therapeutics have been inserted into the backbone of the viral vectors which target amyotrophic lateral sclerosis, coagulation disorders, spinocerebellar ataxia, and tumor oncogenes [46-48].

However, viral vectors may have high immunogenicity and develop resistance due to the high probability of encountering pre-existing immunity in humans $[20,32]$. This potential challenge is exemplified when multiple doses of the therapeutics are required. In addition, efforts still need to be made to overcome the limited packaging capacity of AAVs ( 4.7 kilobases) [45] and the slow onset of gene expression [48]. Other necessary precautions using viral based methods include analyses of repeated dosing, tolerability, long-term expression, efficacy, the ability to regulate expression, and off target effects $[20,32]$. For further review of viral vector refer to $[45,49,50]$.

\subsection{Nanoparticles}

Nanoparticles, both synthetic or lipid based (liposomes), have been the most commonly used non-viral delivery vehicle for siRNA and mRNA vaccines, based on their manufacturing scalability, small size, shape, engineered for targeting or enhanced circulation time, and ability to protect entrapped nucleotides [7, 51, 52]. Lipid nanoparticles have shown preclinical and clinical utility in delivering nucleic acids for liver diseases, cancers, and most recently, in the COVID-19 mRNA based vaccines $[53,54]$. Most of the lipid-based particles, liposomes, include a cationic or ionizable lipid to enhance RNA entrapment, but the positive net charge may lead to increased toxicity [53, 55]. Liposomes may activate complement through the absorption of opsonins and coagulation factors which ultimately leads to phagocytosis, cell stress, inflammation, and apoptosis [55]. Often, a PEG molecule is lipid anchored to increase nanoparticle half-life in vivo, reduce particle size, prevent aggregation during storage, and reduce uptake by unintended targets such as red blood cells and macrophages [55, 56]. However, PEGylation reduces cellular uptake and silencing efficacy of the siRNA by sterically blocking liposome and endosomal membrane interaction [56, 57]. Overall, current delivery modifications and vectors have limitations, and further advancements are necessary for efficient systemic administration of nucleotide therapies. For further view of nanoparticles $[53,55]$.

\section{EVS: NATURAL DELIVERY VECTORS OF NUCLEIC ACIDS}

Extracellular vesicles are a heterogenous class including three major subtypes, apoptotic bodies $(50 \mathrm{~nm}-5,000 \mathrm{~nm})$, microvesicles $(100 \mathrm{~nm}$ to $1 \mu \mathrm{m})$ and exosomes $(30 \mathrm{~nm}-$ $150 \mathrm{~nm}$ ) differentiated by size, content and mechanism of formation [58-61]. Due to the heterogeneity of EVs and the expanding utility as therapeutics and delivery vectors, we will use the term EVs as an encompassing characterization for the use of exosomes as delivery vectors [62]. During EV biogenesis, EVs are loaded with functional genetic components including DNA, RNA, and proteins that modulate the phenotypes of recipient cell lines [61, 63]. Additionally, EVs have been sourced from various cell lines including neural stem cells, mesenchymal stromal cells, dendritic cells, and others as acellular therapeutics for diseases like stroke, myocardial infarction, and others creating a synergistic therapeutic compound and delivery vector [31, 64-67].

\subsection{Inherent loading of genetic material}

The biogenesis of EVs, specifically exosomes (Fig. 2), is initiated by the formation of endocytic vesicles from the inward budding of plasma membrane. This process is followed by subsequent inward budding of the early endosome and acidification of the endosome resulting in multivesicular bodies (MVBs) containing intraluminal vesicles [68-70]. There are two main pathways that form multivesicular bodies and internalized intraluminal vesicles, endosomal sorting complex required for transport (ESCRT) dependent and independent [71, 72]. Upon the maturation of the multivesicular body, the ILVs are shuttled to the plasma membrane and released into the extracellular environment - at which point they are termed exosomes [68].

During the EV biogenesis process, cellular machinery packages nucleic acids, specifically, RNA into the lumen of EVs for intercellular delivery [71]. RNAs are highly enriched into EVs due to their small size, high abundance, ability to associate with membranes and cytoplasmic location [61]. Initial studies have shown that EVs contained mRNAs, miRNAs, small nuclear RNAs, tRNAs, and others, with a peak size of 200 nucleotides and extending out to $5 \mathrm{~kb}$ or more [61]. Several 
mechanisms have been connected with RNA packaging including RNA sequence motifs, secondary configuration, differential affinity for membrane lipids and association with RNA binding proteins including ALG Interacting Protein X, ALIX, annexin A2, major vault protein MVP, and others $[61,73]$. Similarly, other sorting motifs comprise of RNA or RNA binding protein modifications including ubiquitylation, sumoylation, phosphorylation and uridylation [74]. It is evident that several mechanisms play a role in the complex process of cargo loading into EVs thereby making it challenging to 'hijack' the loading system of cells to endogenously load EVs with nucleic acids.

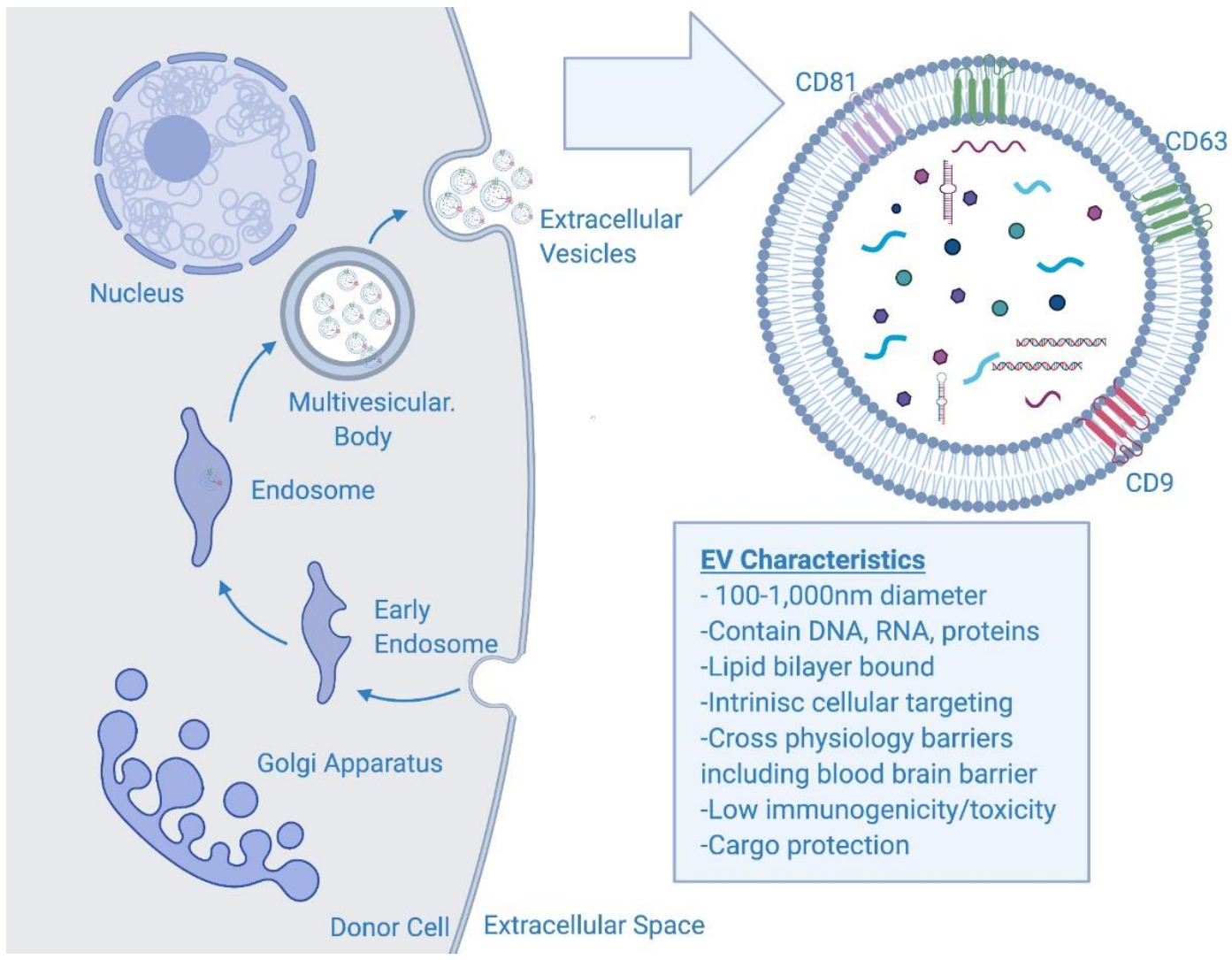

Figure 2. Schematic of EV biogenesis and contents. EVs are formed by the invagination of the early endosome to form the multivesicular body (MVB). In the MVB, the vesicles are coined intraluminal vesicles, and shuttled to be released by the plasma membrane. Once released, the ILVs are coined exosomes or generally extracellular vesicles. EV cargo consists of DNA, RNA, proteins, lipids. The EV membrane contains common tetraspanin proteins including CD9, CD63, and CD81.

\subsection{Natural membrane protection and tropism}

The EV lipid bilayer protects nucleic acid cargo from serum nuclease degradation, similar to nanoparticle delivery [63] even when EVs were administered into harsh in vitro environments with nucleases, proteases, and various proteolytic enzymes or into circulation and cargo remained functional [29]. Mesenchymal cell derived EVs have enhanced retention compared to liposomes, in the circulation of mice due to CD47-mediated protection, 'don't eat me' signal, against phagocytic cells [75]. In addition, the EV membrane resembles the parent cell with a similar lipid profile, integrins, and adhesion proteins that may influence target cell uptake [76, 77] which determines possible interaction with similar cells to parent cell, where for instance, a HEK293T EV were internalized by HEK293T cells [78]. Similar to nanoparticles, EVs may get trapped in the liver and kidney, but targeting can be enhanced through EV surface modification [79]. For instance, RVG peptides have been engineered onto a common EV marker, Lamp2B to enhance targeting to neurons $[31,80]$. Other groups have used similar techniques to target specific tumors and cancer cells [30, 77]. EVs have natural protective and targeting capacity making them an ideal vector to protect nucleic acids in the extracellular space. For further reviews and tables on engineered targeting refer to $[10,77,81,82]$. 


\subsection{Ability to cross physical barriers}

The appeal of harnessing EVs as gene therapy delivery systems stems from their inherent ability to transfer functional biological molecules from cell to cell. Physical barriers including tissue, cellular, and intracellular barriers impede conventional delivery systems. Although the blood brain barrier, is impermeable to over $98 \%$ of small molecules, EVs traverse the BBB via a transcytosis mechanism of the neurovascular cell types $[12,31,83-$ 86]. The majority of EV uptake in recipient cells occurs via an active endocytosis mechanisms, thus allowing EVs to shuttle cargo past the plasma membrane [87-89]. Notably, EVs can be internalized by cells in as little as 30 minutes [78], without surface aggregation, whereas in a head to head comparison of loaded synthetic nanoparticles aggregate on the surface and have 1.7 times lower uptake [90]. Though uptake occurs via endocytosis, EVs were shown to bind with the endosome and release their active cargo into the cytoplasm prior to transcytosis (recycling into extracellular milieu), or degradation by the lysosome [91]. These recent studies indicate that EVs are natural protective delivery vectors of endogenous genetic cargo making them an alluring alternative to synthetic vectors.

\subsection{Low immunogenicity and toxicity profile}

While demonstrating efficacy to deliver therapeutic payloads, EVs have also been assessed for safety in the preclinical setting. EVs have low immunogenicity and toxicity due to their natural characteristics $[29,75,92,93]$. In a comprehensive cross species study, HEK293T EVs dose response safety and toxicity were assessed in C57BL/6 mice, showing minimal immune responses and no signs of toxicity [94]. Since EVs are sourced from various cell types, other groups have shown that tumor derived "microparticles" were feasible and safe [95]. Even at high doses, there were no detected signs of hepatotoxicity [96]. Importantly, EVs have been repeatedly dosed in pre-clinical models with no reported signs of rejection after an initial dose [31, 64, 94]. Essentially, EVs sourced from various cell types all have presented with encouraging safety profiles.

\subsection{Synergistic therapeutic benefits}

Despite the immense potential of EVs as delivery vectors, it is important to acknowledge that EVs sourced from various therapeutic cells specifically stem and progenitor cells have innate therapeutic capacity for a multitude of diseases. EVs have been isolated from neural stem cells (NSCEVs) and mesenchymal stem/stromal cells (MSCEVs), demonstrating the therapeutic potential of their parent cell lines, anti-inflammatory properties and enrichment of specific miRNAs [97]. NSCEVs improved tissue and functional recovery in both a mouse and porcine ischemic stroke model [64, 65]. Similarly, cardiosphere and MSC derived EVs have decreased stroke induced neurodegeneration, inflammation, and neurological deficits [98-100]. Other targeted areas with early efficacy of EVs as acellular therapeutics include myocardial infarction [101, 102], utilization in cancer vaccines [103], immune disorders [104], and brain injury including stroke and epilepsy [105-107]. Depending on the EV source, researchers can capitalize on the synergistic therapeutic and delivery capabilities.

\section{TECHNIQUES FOR LOADING EVS}

EVs provide immense potential as delivery vectors, but precise loading nucleic acids into EVs has not been an easy or standard task. Loading of nucleic acids into EVs can be subdivided into two main categories 1) PreIsolation (Table 2) and 2) Post-isolation (Table 3). As a relatively nascent field, there are advantages and disadvantages to each method that must be accounted for depending on the therapeutic indication.

\subsection{Pre-isolation loading methods}

Loading prior to isolating EVs, often referred to as endogenous loading, hijacks inherent EV loading machinery and processes. Whether it be overexpression via chemical transfection of the exogenous cargo or harnessing the RNA loading machinery of EV donor cells, the therapeutic RNA is loaded into EVs through its intrinsic cellular mechanisms.

\section{Overexpression of Exogenous Nucleic Acids}

Overexpression of nucleic acids has been a commonly used strategy to load therapeutic miRNA into EVs. Briefly, the parent cells are chemically transfected with commercial transfection agents to increase the amount of cytosolic miRNA that may get into EVs prior to being released from these cells [30]. In the parent cells, free floating miRNA are engulfed by the invagination of the multivesicular bodies along with the other genetic contents $[61,108]$. Several proof of principle studies have overexpressed miRNA or mRNA in hMSC lines, CD34+ stem cells, U87 Glioblastoma cells, T-regulatory cells, and HEK293T cells (Table 1.2) to treat Huntington's Disease, Schwann Cell Cancers, breast cancers, and other indications [30, 109, 110]. For instance, MSC EVs loaded with miR-146 decreased targeted EGFR and NFK-B protein levels in a mouse tumor model along with miR124 delivery to promote neuroprotection after a brain infarct [111]. Using similar methods, siRNA targeted 
transforming growth factor Beta-1 was transfected into mouse fibroblasts to generate EVs that suppressed tumor growth in mice [112]. Plasmid DNA encoding Cre recombinase was transfected into parent cells, subsequently loaded into EVs, and detected in recipient cells providing further support for the feasibility of EVbased delivering of reporter molecules and therapeutics in vivo [113].

Table 2. An overview of Pre-Isolation methods of EV loading of nucleic acids. Techniques include overexpression via transfection, electroporation, TAMEL, and EXOtic systems to exploit endogenous loading of nucleic acids into EVs.

\begin{tabular}{|c|c|c|c|c|c|c|}
\hline \multicolumn{7}{|c|}{ Pre-Isolation EV Loading } \\
\hline $\begin{array}{l}\text { Author } \\
\text { (source) }\end{array}$ & Method & EV Source & Cargo & Target & Disease & Result \\
\hline Hung 2016 & $\begin{array}{l}\text { TAMEL } \\
\text { Platform }\end{array}$ & HEK293T & mRNA & $\begin{array}{l}\text { Non- } \\
\text { Specific }\end{array}$ & $\begin{array}{l}\text { Prostate } \\
\text { Cancer }\end{array}$ & $\begin{array}{l}\text { Loading of mRNA was } \\
\text { efficient, but minimal } \\
\text { fucntional efficacy in } \\
\text { recipeint cells. }\end{array}$ \\
\hline $\begin{array}{l}\text { Katakowski } \\
2012\end{array}$ & $\begin{array}{l}\text { Transfected } \\
\text { Cell Line }\end{array}$ & hMSC & miRNA & $\operatorname{miR}-146$ & Glioma & $\begin{array}{l}\text { Decreased EGFR and } \\
\text { NF-KB protein levels and } \\
\text { significant reduction in } \\
\text { xenotransplanted tumor } \\
\text { volume }\end{array}$ \\
\hline Kojima 2018 & EXOtic Device & HEK293T & mRNA & Catalase & $\begin{array}{l}\text { Parkinson's } \\
\text { Disease }\end{array}$ & $\begin{array}{l}\text { Attenuation of } \\
\text { neurotoxicity and } \\
\text { neuroinflammation in in } \\
\text { vitro and in vivo }\end{array}$ \\
\hline Kosaka 2012 & Stable Cell Line & $\begin{array}{l}\text { HEK293T } \\
\text { Cell Media } \\
\text { (not isolated } \\
\text { EVs) }\end{array}$ & miRNA & $\operatorname{miR}-143$ & $\begin{array}{l}\text { Prostate } \\
\text { Cancer }\end{array}$ & $\begin{array}{l}50 \% \text { decrease in cell } \\
\text { proliferation and decrease } \\
\text { in tumor size with } \\
\text { knockdown of KRAS }\end{array}$ \\
\hline Lee 2017 & $\begin{array}{l}\text { Stable Cell } \\
\text { Line* } \\
\text { (Lipofectamine) }\end{array}$ & HEK293T & miRNA & $\operatorname{miR}-124$ & $\begin{array}{l}\text { Huntington's } \\
\text { Disease }\end{array}$ & $\begin{array}{l}\text { Decreased REST protein } \\
\text { expression, but minimal } \\
\text { behavioral changes in } \\
\text { mice }\end{array}$ \\
\hline $\begin{array}{l}\text { Mathiyalagan } \\
\text { (protocol) } \\
2017\end{array}$ & $\begin{array}{l}\text { Transfected } \\
\text { Cell Line }\end{array}$ & $\begin{array}{l}\text { CD34+ Stem } \\
\text { Cells }\end{array}$ & miRNA & $\begin{array}{l}\text { Non- } \\
\text { Specific }\end{array}$ & N/A & $\begin{array}{l}\text { Significant uptake of Cy3 } \\
\text { siRNA into HUVECs }\end{array}$ \\
\hline Mizrak 2013 & $\begin{array}{l}\text { Transfected } \\
\text { Cell Line }\end{array}$ & HEK293-T & mRNA/Protein & $\begin{array}{l}\text { CD-UPRT } \\
\text { Pathway } \\
\text { (cell Death) }\end{array}$ & $\begin{array}{l}\text { Schwann } \\
\text { Cell Cancer }\end{array}$ & $\begin{array}{l}\text { Inhibition of } \\
\text { schwannoma tumor } \\
\text { growth in mice } 99\end{array}$ \\
\hline Munoz 2013 & Stable Cell Line & U87, T98G & miRNA & miR-9 & Glioblastoma & $\begin{array}{l}50 \% \text { decrease in miR9 } \\
\text { levels }\end{array}$ \\
\hline Ohno 2013 & $\begin{array}{l}\text { Transfected } \\
\text { Cell Line }\end{array}$ & HEK293T & miRNA & Let7 & $\begin{array}{l}\text { Breast } \\
\text { Cancer }\end{array}$ & $\begin{array}{l}\text { Inhibited targeted } \\
\text { luciferase gene and } \\
\text { decrease luciferase } \\
\text { activity of tumor cells in } \\
\text { xenotransplanted mice, } \\
\text { suppressed cancer }\end{array}$ \\
\hline Okoye 2014 & $\begin{array}{l}\text { Transfected } \\
\text { Cell Line }\end{array}$ & $\begin{array}{l}\text { T-Regulatory } \\
\text { Cells }\end{array}$ & miRNA & Let-7d & $\begin{array}{l}\text { Systemic } \\
\text { Disease }\end{array}$ & Th1 cell suppression \\
\hline Pan 2014 & $\begin{array}{l}\text { Transfected } \\
\text { Cell Line }\end{array}$ & Hela -229 & miRNA & miR-130B & Obesity & $\begin{array}{l}\text { Down regulation of of } \\
\text { PPAR- } \gamma \text { Expression, } \\
\text { inhibited adipogenesis } \\
\text { and lipogenesis }\end{array}$ \\
\hline Sutaria 2017 & $\begin{array}{l}\text { Transfected } \\
\text { Cell Line }\end{array}$ & HEK293T & miRNA & $\begin{array}{l}\text { pre-miR- } \\
199 a\end{array}$ & N/A & $\begin{array}{l}\text { Minimal therapeutic } \\
\text { efficacy }\end{array}$ \\
\hline Yang 2017 & Electroporation & $\begin{array}{l}\text { Murine BM- } \\
\text { MSC }\end{array}$ & miRNA & miR-124 & Brain Infarct & $\begin{array}{l}\text { Promoted cortical neural } \\
\text { progenitors to obtain } \\
\text { neuronal identity and } \\
\text { protect against ischemic } \\
\text { injury by robust cortical } \\
\text { neurogenesis. }\end{array}$ \\
\hline
\end{tabular}




\begin{tabular}{|lllllll|}
\hline Zhang 2014 & $\begin{array}{l}\text { Transfected } \\
\text { Cell Line }\end{array}$ & $\begin{array}{l}\text { Mouse } \\
\text { fibroblast } \\
\text { L929 cells }\end{array}$ & siRNA & TGF-Beta1 & $\begin{array}{l}\text { Tumor } \\
\text { Cancer }\end{array}$ & $\begin{array}{l}\text { Suppression of S180 } \\
\text { tumor growth in mice }\end{array}$ \\
\hline
\end{tabular}

Delivering miRNA and siRNA by EVs is encouraging; however, several challenges remain. Recent evidence suggests that EVs, specifically microvesicles, effectively delivered mRNA and siRNA cargos into targeted recipient cells, but these nucleic acids were rapidly degraded without translation into protein thereby decreasing the desired knockdown of the target genes [113]. Secondly, potential contamination of transfection agents in the EV samples may be a source of false positive data readouts. Further, the overexpression model is not applicable to miRNAs that are detrimental to the donor cell thereby inhibited proliferation, homeostasis, or general EV biogenesis [93]. Further, loading efficiencies may vary depending on the treatment conditions and state of the parent cell $[112,114]$. Due to these challenges, there have been advancements in engineering the cargoes by exploiting the loading machinery for therapeutic proteins [72].
Recently, using a cellular nanoporation method, plasmid DNA was transfected into donor cells and the secreted EVs then contained therapeutic mRNA. Nanoporation systems consist of source cells cultured above a synthetic microchip which contains nanochannels that enable the transient passage of electrical pulses to form nanopores into the cells. This novel technique resulted in a significant increase of specific mRNA transcripts in the EVs which in turn inhibited tumor growth and increase survival in a glioma murine model [115]. Nanoporation may be an alternative to chemical transfection, but more studies need to be done to support its reproducibility and efficacy. The authors showed that cellular nanoporation produced up to 50 -fold more exosomes and greater than $10^{3}$ fold increase in exosomal mRNA transcripts compared to bulk electroporation [115]. Though this study has been done in mRNA, the fundamentals should be translatable to and explored in loading other therapeutic oligonucleotides.

Table 3. An overview of Post-Isolation Methods of EV loading of Nucleic Acids. Techniques include electroporation, sonication, co-incubation, transfection, and peptide tagging.

\begin{tabular}{|c|c|c|c|c|c|c|}
\hline \multicolumn{7}{|c|}{ Post-Isolation Loading } \\
\hline $\begin{array}{l}\text { Author } \\
\text { (source) }\end{array}$ & Method & EV Source & Cargo & Target & Disease & Result \\
\hline $\begin{array}{l}\text { Alvarez- } \\
\text { Erviti } 2011\end{array}$ & Electroporation & $\begin{array}{l}\text { Murine } \\
\text { Dendritic } \\
\text { Cells }\end{array}$ & siRNA & $\begin{array}{l}\text { BACE1 } \\
\text { and } \\
\text { GAPDH }\end{array}$ & $\begin{array}{l}\text { Alzheimer's } \\
\text { Disease }\end{array}$ & $\begin{array}{l}\text { Dose dependent knnockdown } \sim 50 \% \text { and } \\
\text { iRNA delivery was demonstrated by the } \\
\text { strong mRNA }(60 \%) \text { and protein }(62 \%) \\
\text { knockdown of BACE1, a therapeutic } \\
\text { target in Alzheimer's disease }\end{array}$ \\
\hline $\begin{array}{l}\text { Andaloussi } \\
2012\end{array}$ & Electroporation & $\begin{array}{l}\text { Dendritic and } \\
\text { HEK293T }\end{array}$ & siRNA & BACE1 & $\begin{array}{l}\text { Alzheimer's } \\
\text { Disease }\end{array}$ & Significant target gene knockdown \\
\hline Aqil 2018 & $\begin{array}{l}\text { Electroporation } \\
\text {, Chemical } \\
\text { Transfection }\end{array}$ & Bovine Milk & siRNA & $\begin{array}{l}\text { VEGF, } \\
\text { EGFR, } \\
\text { AKT< } \\
\text { MAPK, } \\
\text { KRAS }\end{array}$ & Cancer & $\begin{array}{l}\text { a dose-dependent anti-proliferative } \\
\text { activity against A549 cells with 5-fold } \\
\text { reduction of EGFR levels compared to } \\
\text { vehicle and significant reduction in } \\
\text { tumor xenografts. Chemical transfection } \\
\text { > electroporation }\end{array}$ \\
\hline Bai 2019 & Electroporation & HEK293T & siRNA & SOX2 & Lung Cancer & $\begin{array}{l}\text { Increased knockdwon of SOX } 2 \text { mRNA } \\
\text { compared to lipofectamine }\end{array}$ \\
\hline $\begin{array}{l}\text { Cooper } \\
2014\end{array}$ & Electroporation & $\begin{array}{l}\text { Murine } \\
\text { Dendritic } \\
\text { Cells }\end{array}$ & siRNA & Alpha-Syn & $\begin{array}{l}\text { Parkinson's } \\
\text { Disease }\end{array}$ & $\begin{array}{l}\text { Downregulation of endogenous } \alpha \text { - } \\
\text { synuclein in normal mouse brain and } \\
\text { human phospho-mimic human S129D } \alpha \text { - } \\
\text { Syn in transgenic mouse }\end{array}$ \\
\hline $\begin{array}{l}\text { Faruqu } \\
2018\end{array}$ & Electroporation & HEK293 & siRNA & $\begin{array}{l}\text { Non- } \\
\text { Specific }\end{array}$ & $\begin{array}{l}\text { Pancreatic } \\
\text { Cancer }\end{array}$ & $\begin{array}{l}\text { SiRNA was internalized into } 40 \% \text { of } \\
\text { cells. }\end{array}$ \\
\hline $\begin{array}{l}\text { Gujrati } \\
2014\end{array}$ & Electroporation & $\begin{array}{l}\text { E. Coli (K12 } \\
\text { W3110 with } \\
\text { msbB } \\
\text { mutation) }\end{array}$ & siRNA & $\begin{array}{l}\text { Kinesin } \\
\text { Spindle } \\
\text { Protein }\end{array}$ & Her2 Cancer & $\begin{array}{l}\text { targeted gene silencing and induced } \\
\text { highly significant tumor growth } \\
\text { regression }\end{array}$ \\
\hline
\end{tabular}




\begin{tabular}{|c|c|c|c|c|c|c|}
\hline $\begin{array}{l}\text { Kamerkar } \\
2017\end{array}$ & Electroporation & hMSC & siRNA & KRAS & $\begin{array}{l}\text { Pancreatic } \\
\text { Cancer }\end{array}$ & $\begin{array}{l}\text { Suppression of cancer in multiple mouse } \\
\text { models of pancreatic cancer and } \\
\text { significant increase in survival. }\end{array}$ \\
\hline $\begin{array}{l}\text { Koojimans } \\
2013\end{array}$ & Electroporation & $\begin{array}{l}\text { N2A and } \\
\text { HEK293T }\end{array}$ & siRNA & $\begin{array}{l}\text { Non- } \\
\text { Specific }\end{array}$ & N/A & $\begin{array}{l}\text { Induction of strong aggregation of } \\
\text { siRNA }\end{array}$ \\
\hline $\begin{array}{l}\text { Lamichhan } \\
\text { e } 2015\end{array}$ & Electroporation & HEK293T & dsDNA & $\begin{array}{l}\text { Ser (CGA) } \\
\text { Gene }\end{array}$ & N/A & $\begin{array}{l}\text { Functional gene delivery was not } \\
\text { observed. }\end{array}$ \\
\hline Liu 2015 & Electroproation & HEK293T & siRNA & $\begin{array}{l}\text { Opiod } \\
\text { Receptor } \\
\mathrm{Mu}\end{array}$ & & $\begin{array}{l}\text { Downregulating MOR expression levels } \\
\text { in mouse brain }\end{array}$ \\
\hline $\begin{array}{l}\text { Pomatto } \\
2019\end{array}$ & $\begin{array}{l}\text { Electroporation } \\
\text {, Co-Incubation }\end{array}$ & Plasma & miRNA & $\begin{array}{l}\text { Cel39, } \\
\text { miR31, } \\
\text { miR-451A }\end{array}$ & Hepatocarcinoma & $\begin{array}{l}\text { Increase cancer cell apoptosis (higher } \\
\text { effect following electroporation vs. co- } \\
\text { incubation) }\end{array}$ \\
\hline $\begin{array}{l}\text { Usman } \\
2018\end{array}$ & Electroporation & $\begin{array}{l}\text { Red Blood } \\
\text { Cells }\end{array}$ & ASO & MiR-125 & $\begin{array}{l}\text { Acute Myeloid } \\
\text { Leukemia }\end{array}$ & $\begin{array}{l}\text { Dose dependent knockdown of miR- } \\
125 \mathrm{~A} / \mathrm{B} \text { and decreased tumor size with } \\
\text { suppression of AML progression }\end{array}$ \\
\hline $\begin{array}{l}\text { Usman } \\
2018\end{array}$ & Electroporation & $\begin{array}{l}\text { Red Blood } \\
\text { Cells }\end{array}$ & $\begin{array}{l}\text { Cas9 } \\
\text { mRNA }\end{array}$ & N/A & N/A & $\begin{array}{l}\text { Cas } 9 \text { protein was efficiently expressed } \\
\text { in the nuclei of } \sim 50 \% \text { MOLM } 13\end{array}$ \\
\hline $\begin{array}{l}\text { Usman } \\
2018\end{array}$ & Electroporation & $\begin{array}{l}\text { Red Blood } \\
\text { Cells }\end{array}$ & $\begin{array}{l}\text { Plasmi } \\
\text { d DNA }\end{array}$ & $\begin{array}{l}\text { GFP } \\
\text { Marker }\end{array}$ & N/A & $\begin{array}{l}\text { EGFP knockout was observed in only } \\
\sim 10 \% \text { cells }\end{array}$ \\
\hline $\begin{array}{l}\text { Wahlgren } \\
2012\end{array}$ & Electroporation & $\begin{array}{l}\text { Plasma, Lung } \\
\text { cancer, and } \\
\text { HeLA Cells }\end{array}$ & siRNA & MapK1 & N/A & $\begin{array}{l}\text { Cell death of targeted } \\
\text { monocytes, Silencing of MAPK1 in } \\
\text { monocytes and lymphocytes } \\
\text { Suppression }\end{array}$ \\
\hline Shtam 2013 & Electroproation & HeLA & siRNA & Rad51/52 & Cancer & $\begin{array}{l}\text { siRNA against RAD51 was functional } \\
\text { and caused the massive reproductive cell } \\
\text { death of recipient cancer cell }\end{array}$ \\
\hline $\begin{array}{l}\text { Lamichann } \\
\text { e } 2016\end{array}$ & Sonication & MCF-7 & siRNA & Her2 & Breast Cancer & Knockdown of HER2 mRNA \\
\hline Yang 2017 & $\begin{array}{l}\text { Chemical } \\
\text { Transfection }\end{array}$ & $\begin{array}{l}\text { Brain } \\
\text { Endothelial }\end{array}$ & siRNA & VEGF & Glioblastoma & $\begin{array}{l}\text { Cells treated with siRNA alone } \\
\text { demonstrated a knockdown of } 40 \% \text { of } \\
\text { VEGF and decreased tumor proliferation } \\
\text { in vitro }\end{array}$ \\
\hline Zhang 2017 & $\begin{array}{l}\text { Calcium } \\
\text { Transfection }\end{array}$ & $\begin{array}{l}\text { THP-1, } \\
\text { RAW 264.7, } \\
\text { MH-S, Bone } \\
\text { Marrow } \\
\text { macrophage } \\
\text { (BMDM), or } \\
\text { BALF }\end{array}$ & miRNA & miR-15A & N/A & $\begin{array}{l}\text { Efficient overexpression or deletion of } \\
\text { the designated miRNAs in the recipient } \\
\text { cells both in vivo and in vitro. }\end{array}$ \\
\hline $\begin{array}{l}\text { Biscans } \\
2018 \\
\end{array}$ & Co-Incubation & $\begin{array}{l}\text { Umbilical } \\
\text { MSCs }\end{array}$ & siRNA & Htt Gene & $\begin{array}{l}\text { Huntingon's } \\
\text { Diseae }\end{array}$ & $20-80 \%$ knockdown of target gene \\
\hline Didiot 2017 & Co-Incubation & U87 & siRNA & Htt Gene & $\begin{array}{l}\text { Huntingon's } \\
\text { Diseae }\end{array}$ & $\begin{array}{l}\text { dose-dependent silencing of Htt mRNA, } \\
\text { up to } 75 \% \text { reduction and HTT protein up } \\
\text { to } 68 \% \text { reduction and bilateral silencing } \\
\text { of up to } 35 \% \text { of Huntingtin mRNA. }\end{array}$ \\
\hline Gao 2018 & $\begin{array}{l}\text { Co-Incubation } \\
\text { (Peptide } \\
\text { Tagging) }\end{array}$ & & ASO & $\begin{array}{l}\text { Dystrophin } \\
\text { Gene }\end{array}$ & $\begin{array}{l}\text { Muscular } \\
\text { Dystrophy }\end{array}$ & $\begin{array}{l}18 \text {-fold Increase in dystrophin } \\
\text { expression in muscular dystrophy mouse } \\
\text { model compared to naked ASO }\end{array}$ \\
\hline $\begin{array}{l}\text { Haraszti } \\
2018\end{array}$ & Co-incubation & U87 & siRNA & Htt Gene & $\begin{array}{l}\text { Huntingon's } \\
\text { Diseae }\end{array}$ & $50 \%$ knockdown of target gene \\
\hline $\begin{array}{l}\text { Stremersch } \\
2016 \text { (EV } \\
\text { Like) }\end{array}$ & Co-Incubation & $\begin{array}{l}\text { B16F10 } \\
\text { Melanoma } \\
\text { Cells and } \\
\text { JAWSII }\end{array}$ & siRNA & CD45 & N/A & $\begin{array}{l}\text { Only liposome delivery provided } \\
\text { knockdwon of target gene. Anionic } \\
\text { fusogenic liposomes outperform ELVs } \\
\text { in chol-siRNA delivery in vitro }\end{array}$ \\
\hline
\end{tabular}

\section{Engineering Cargo to Enhance Loading Selectivity}

To enhance loading of EVs prior to isolation, the natural loading machinery in the donor cell has been exploited. Although canonical miRNAs may be abundant in cells, this does not effectively correlate to high copy numbers of miRNA into small EVs. The integration of a pre-miR- 451backbone, the most abundant miRNA in small EVs, with siRNA was shown to enrich siRNA by 100 to 10,000 fold into EVs [116]. Similarly, 'Designer Exosomes' were created by binding L7Ae, a ribosomal protein to CD63 to hijack delivery into CD63 expressing EVs. From there, therapeutic mRNA was co-expressed in the producer cell which binds to the L7Ae protein and subsequently 
delivered into EVs for downstream therapeutic applications [117]. Similarly, Lamp2B, a common exosomal protein was tagged with the MS2 bacteriophage coat protein dimer, a well characterized RNA binding protein, to enhance EV mRNA loading in HEK293FT cells [118]. This platform resulted in a 6-fold increase of RNA compared to cells without MS2 revealing that loading of RNA up to $1.5 \mathrm{~KB}$ is feasible. However, when loaded EVs were internalized by recipient cells, the nucleic acids were trapped in the endosome and degraded [118]. Further to enhance miRNA loading, pre-miR199a attached to Lamp2A, with a modified TAR RNA loop to exploit the TAT peptide/HIV-1 transactivation response (TAR) RNA interacting peptide. This motif resulted in a 65-fold enrichment of the miR-199a-3p in the EVs compared to cells without the TAT construct, but the EV delivered miRNA was functionally inefficient in recipient cells [119]. Despite these shortcomings in functional efficacy, engineering the parent cells does result in loading of EVs with therapeutic cargo.

\section{Exosome Adeno-associated Virus Hybrids}

To synergize the utility of both extracellular vesicles, exosomes specifically, and viral vectors, several groups have created Exo-AAV hybrids for the delivery of transgenes. Specifically, cells transfected with AAVs produce an AAV population that interacts with extracellular vesicles and have an improved functional readout compared to vesicle-free AAVs. Exo-AAVs have been shown to traverse more efficiently through biological barriers including the BBB or the inner limiting membrane of the retina after both systemic and intravitreal injection. Building on the premise, exosomeAAVs were used to deliver transgenes into cochlear and vestibular hair cells both in vitro and in vivo. Compared to conventional AAVs with transduction of $20 \%$ in targeted cells, exo-AAVs transduced upwards of 50-65\% in targeted cells in the ear [120].

\subsection{Post-isolation loading techniques}

Post-isolation or exogenous loading encompasses a variety of techniques to load nucleic acid therapeutics into extracellular vesicles. As compared to pre-isolation methods, post-isolation permits for a wider array of therapeutics to be loaded without the detriment of altering the parent cell line. Another major advantage of using post-isolation techniques is the wide range of $\mathrm{EV}$ producer cells since it is not limited to cell types that are easily transfected or contain efficient intrinsic cell machinery. Post isolation loading can be standardized and controlled whereas the pre-isolation is EV biogenesis and cell state dependent and may vary depending on conditions [114].

\section{Electroporation}

Initially designed to disrupt the cellular membrane for transfection by creating small pores for cargo to enter, electroporation has been used to load nucleic acids into EVs secreted from murine dendritic cell, HEK293T bovine milk, N2A, red blood cells, fiboblasts among others [29, 31, 61, 121-123]. Electroporation functions by passing volts through the isolated EVs in suspension to form small pores in the lipid bilayer allowing for entry/exit of cargo [124]. Using electroporation, glyceraldehyde 3-phosphate dehydrogenase, GAPDH and beta-secretase 1, BACE1 siRNA were loaded into engineered dendritic cell-derived EVs and delivered to the brain in a rodent model. This study showed significant dose dependent knockdown of target mRNA and protein, with 25\% loading efficiently and ability to deliver functional siRNA across the blood brain barrier [31]. Using the same loading technique and EV source, alphasynuclein targeting siRNA loaded EVs administered peripherally resulted in significant reductions in intraneuronal protein aggregates in dopaminergic neurons of the substantia nigra for the treatment of Parkinson's Disease [122]. The two aforementioned EVs were engineered with a rabies viral glycoprotein modality on lysosomal-associated membrane protein 2B (LAMP-2B) to enhance targeting to neurons in the central nervous system (CNS). Importantly, the EVs preferentially targeted neurons and successfully traversed the blood brain barrier in Alzheimer's Disease and Parkinsonian mice [31, 122].

Similarly, bovine milk EVs electroporated with siRNA targeting VEGF, EGFR, and other cancer biomarkers had low loading efficiency of around 4-5\%, but showed anti-proliferative effects in vitro and in vivo [121]. EVs with targeting peptides for lung cancer cells displayed a $20 \%$ encapsulation efficiency with electroporation and notable gene silencing effect in vitro [125]. More recently, EVs from fibroblasts transfected with Epstein Barr Virus induced cDNA were electroporated with siRNA resulting in significant in vitro and in vivo tumor-suppressive effects [123]. Another study assessed electroporation in red blood cell EVs, using antisense oligonucleotides, Cas 9 mRNA, and plasmid DNA cargos. [29]. Electroporation resulted in 20$24 \%$ of ASO and $18 \%$ of Cas9 mRNAs loaded into EVs with high functional effects, but with decreased effects when delivering larger plasmid DNA [29]. Similarly, exogenous linear DNA can be associated with EVs via electroporation resulting in an average of hundreds of DNA molecules per vesicle, but functional gene delivery 
was not observed [126]. These studies support the wide applicability of electroporation to load EVs with therapeutic nucleic acids to modulate recipient cells.

Electroporation has fundamental pitfalls in data interpretation, potential decreases in EV integrity, and cargo aggregation [127, 128]. Primarily in a comprehensive study with varying voltages, concentrations of EV and free nucleic acids, and medium, siRNA aggregated [127]. Though this may seem innocuous, aggregation of siRNA can be mistakenly calculated as loaded EVs thereby creating false positive conclusions [127]. Conversely, others have not reported siRNA aggregation nor disruption of the therapeutic cargo [129]. Electroporation may also result in EV aggregation, but these aggregates can be broken up by pipetting [29]. Despite being hypothesized to be agnostic of loading technique, linear DNA loading is limited to molecules less than 1,000 base pairs and these levels are EV size dependent [126]. Although cargo and EV integrity may be hindered by electroporation, the majority of studies have shown efficacious cargo delivery and functional efficacy in target cells.

\section{Sonication}

Sonication is the application of sound energy through the EVs and nucleic acids in suspension to generate micropores in the EV membrane [130]. HEK293T EVs loaded with siRNA, miRNA, and ssDNA by sonication showed an efficient target knockdown and expression of HER2 for treatment of breast cancer [131]. This study showed sonication efficiently loaded siRNA into EVs at a $325 \%$ increase compared to passive loading, preserved the integrity of the cargo, and had significantly lower amount of siRNA aggregation compared to electroporation [131]. When optimizing protocols, sonication did not induce significant EV or siRNA aggregation and resulted in $\sim 12$ fold less large aggregates than those induced by electroporation [131]. Importantly, sonicated EVs had higher cellular uptake than electroporated EVs under the same conditions, which further supports the need to assess sonication as an alternative loading mechanism [131]. However, similar to electroporation, siRNA may adhere to the external membrane of EVs resulting in false positive conclusions.

\section{Chemical Transfection}

Chemical transfection uses an agent to encapsulate the therapeutic cargo and deliver cargo through the EV lipid bilayer membrane. Chemical transfection has shown early efficacy in loading siRNA and miRNA into HeLa, brain endothelial, and macrophage derived EVs [121, 132, 133]. HeLa EVs were transfected with siRNA with delivery into recipient cells [132]. Similarly, EVs loaded with VEGF siRNA had higher increased the cell uptake, more than four times compared to siRNA alone in vitro and decreased tumor size in vivo [134]. In a direct comparison to electroporation, milk EVs were transfected with siRNA resulting in around $30 \%$ efficient loading, whereas electroporation resulted in a 5\% efficiency [121]. A drawback in using chemical transfection agents is the risk potential contamination in the EV sample, where lipofectamine micelles may be indistinguishable from EVs [132]. There have been reports of the lipofectamine merging with the EV membrane thus increasing the size of the EV and potentially altering composition and resulting uptake potential [135]. However, these hybidosome (hybrid liposome/exosomes) may have advantages and were developed to deliver larger cargoes [135]. In summary, transfection provides a viable alternative to sonication and electroporation, but extensive cleanup after loading is required to eliminate the possibility of micelle contamination rather than a homogenous EV sample.

\section{Passive Loading - Co-Incubation}

Passive loading represents a non-invasive strategy to coincubate therapeutic cargo with isolated EVs in a highly scalable manner, which does not involve invasive manipulation or engineering of parent cells or EVs. In many studies, nucleotides chemically modified with cholesterol or similar hydrophobic moieties were cocultured with isolated EVs in solution at $37^{\circ} \mathrm{C}$ to passively associate with the EV membrane [28, 136, 137]. This passive affinity hypothesis was based upon naked nucleotide entry into cells via association with cholesterol [138]. Firstly, loading melanoma cell derived 'exosome like vesicles' (ELVs) which includes a heterogenous mixture of extracellular vesicles and exosomes, with cholesterol tagged siRNA resulted in $80 \%$ of siRNA associated with EVs, equating to 73 molecules of siRNA associate with EVs whereas non-conjugated siRNA had no EV association [139]. However, the loaded siRNA lacked functional effects on gene expression in target cells, possibly due to inefficient endosome escape and subsequent shuttling of the nucleotides to the lysosome for degradation [139]. Further studies are needed to track the therapeutic cargos in recipient cells and evaluate the endosomal escape hypothesis. Additionally, it is reasonable to speculate that an excessively strong anchoring of the cholesterol tagged siRNA onto the EV membrane may hamper activation of the RNAi machinery, where the modified nucleic acids cannot be released from the membrane [139]. On the contrary, other reports supported the efficient association of cholesterol siRNA to the EVs with increased efficiencies by 
increasing the siRNA hydrophobicity [28, 137]. Notably, EV mediated delivery of siRNA targeting the HTT gene resulted in a dose dependent silencing of HTT mRNA and protein when administered via a bolus intrastriatal injection. [28]. Compared to previous studies, $10-50 \%$ of siRNA was associated with EVs equating to $1,000-3,000$ hsiRNA molecules associated per EV which is significantly greater than previous studies [28, 137]. In fact, increasing siRNA to EV ratios yielded higher loading efficiencies with saturation kinetics: at a 1:25,000 sEV-tohsiRNA ratio which resulted in $24 \%$ loading efficiency or between 3-6,000 molecules of siRNA associated with EVs [137]. Additionally, overloading EVs above 3,000 molecules of siRNA decreased functional efficiency [140]. However, the siRNA may not be incorporated in the lumen of the EV but rather associated to the surface [28]. Compared to electroporation and sonication, passively loading EVs with hydrophobically modified nucleotides provides a highly scalable and robust platform thereby increasing the translational potential of EVs as delivery vectors [28]. In a separate study, CP05, an anchor peptide that binds to CD63, was tagged to an antisense oligonucleotide and mixed with EVs resulting in ASO association with the EV membrane at a binding efficiency of $82.5 \%$. Furthermore, the EV associated CP05 anchored ASO was functionally active in increasing dystrophin in a muscular dystrophy mouse mode [141] which provides another avenue of passive EV loading. Additionally, cells overexpressing prostaglandin F2 Receptor negative regulator (PTGFRN), a common EV surface protein and immune activator, produced EVs rich in PTGFRN. The PTGFRN rich HEK293T EVs, termed ExoSTING, were subsequently isolated and co-cultured with cyclic dinucleotides $(\mathrm{CDN})$ for 24 hours resulting in increased CDN tumor immune surveillance efficacy [142]. This preclinical study provides early evidence of the synergistic effects of PTGFRN EVs loaded with cyclic dinucleotides and recently advanced into a Phase 1/2 study [142]. Passive loading provides a high-throughput and non-invasive method of loading EVs and further studies should elucidate the protection capacity of EVs when the therapeutics are associated to the external surface of the EVs.

\section{EVS IN THE CLINIC}

Given the promising results from the preclinical studies, nucleic acid loaded EVs have made it into the clinic. In a Phase $1 / 2$ study of ischemic stroke currently underway, allogeneic MSC EVs, enriched by miR-124 will be assessed for safety in efficacy in a small population (NCT03384433). In a Phase 1 trial IL-12 expressing 'exosomes' were evaluated for safety, tolerability, pharmacokinetics and pharmacodynamics of single ascending doses in healthy volunteers. The study demonstrated an absence of systemic IL-12 exposure in healthy volunteers and confirmed localized exo-IL12 pharmacological activity providing optimism for future trials using EVs to deliver nucleic acids [143]. Looking ahead, a similar study will be conducted in patients with early-stage cutaneous $\mathrm{T}$ cell lymphoma. Building on preclinical findings [142], CDK-002, PTGFRN rich EVs loaded with CDNs will be administrated intratumorally in subjects with advanced/metastatic, recurrent, injectable tumors with emphasis on head and neck squamous cell cancer, triple negative breast cancer, anaplastic thyroid carcinoma and cutaneous squamous cell carcinoma. This open label Phase $1 / 2$ multicenter study focuses on dose escalation, safety, pharmacodynamics and PK (NCT04592484). Further, a trial using MSC-derived EVs loaded with KrasG12 siRNA for the treatment of pancreatic cancer is currently recruiting patients (As of March 4, 2020, NCT03608631). This Phase 1 trial aims to evaluate safety and tolerability of ascending doses of loaded MSC EVs for patients with metastatic pancreatic cancer with the KrasG12D mutation. The limited number of clinically grade EVs may be due to manufacturing challenges such as upstream cell cultivation, downstream purification or general quality control during the EV generation and loading processes [144]. For more information on clinical trials see [145]. For more information on clinical trials refer to the International Society of EVs (ISEV) position paper [146].

\section{CURRENT CHALLENGES AND FUTURE DIRECTIONS}

Harnessing EVs as delivery vectors of nucleic acid cargoes, though promising, must be optimized before before widespread translation to the clinic. Overall, there remains a need for a scalable and sustainable source of homogeneous loaded extracellular vesicles. The field lacks consensus on superior or "best" method for obtaining high yields of pure extracellular vesicles [147]. This may be due to relatively low yields of production by mammalian cells, variable isolation methods, and lack of characterization or quantification techniques [148]. Further, an ISEV position paper supports this notion by stating that EV isolation is not standardized which leads to heterogenous samples creating possible confounding artefacts and misleading information in EV loading, scalability, and manufacturing [62, 149, 150]. Although progress has been made in loading nucleic acids, there is a lack of consensus on how the EV lumen volume limits the quantity and size of the nucleic acid constructs in EVs. One study suggested that DNA molecules of 1,000 base pairs or less were more efficiently associated with EVs than larger linear DNAs and plasmid DNAs [126]. As 
noted previously, there are studies in which successful loading of nucleic acids occurred but did not result in a functional knockdown of target genes. This may be attributed to inefficient dissociation of cholesterol siRNAs from the EV membrane or failed endosome escape of these nucleic acids [113, 126]. Another hypothesis suggests that functional delivery may be dependent on the EV subtype, where microvesicles have had higher efficacy compared to exosome delivery [113]. Though the lacking functional outcome of EV-based delivery of therapeutic nucleic acids may be infrequently reported, the underlying mechanism is worthy of further investigations to mitigate potential risks.

Another potential obstacle to overcome is the targeting of EVs to recipient cells, in vivo. Though we and others have shown EVs to have inherent tropism to specific cells, EVs when administered intravenously often become trapped in the liver, kidney, and lungs [78, 79]. To overcome this challenge, EV membranes have been engineered with targeting modalities including ligands, peptides, and antibodies to enhance organo- and cellular tropism to specific tumors, neurons, and other specific cells $[30,31,77]$. Further work in engineering EVs can be done to increase its utility across EV and recipient cells of interest.

Although there are a variety of possible techniques to load EVs with nucleic acids, loading efficiency is highly variable and each method has specific flaws as discussed above. In post isolation loading techniques, a major challenge is to separate free nucleic acid from loaded EVs. Free nucleic acid is defined as nucleic acid not associated with extracellular vesicles, and thus remains freely suspended in the supernatant. Without proper separation techniques, reported results may overestimate the actual amount of nucleic acids loaded in EVs.

Commonly, the sample mixtures are ultracentrifuged or filtered which may disrupt EV membrane integrity, decrease EV sample yield, and is a low throughput technique [151]. Similarly, few studies have separated non-loaded or 'empty' extracellular vesicles from loaded EVs. Since EV uptake reaches a saturation plateau in recipient cells [78], administering unloaded EVs may be detrimental to the therapeutic utility of the entire sample. EV loading efficiency remains low and often variable due to the loading methodology and post sample cleanup [114, $152,153]$. In passive loading assays where the therapeutic cargo may merely be associated and not internalized by the EVs, studies need to assess the protective capacity of the EVs. Although cholesterol tagged siRNA remained functional in vivo, the intrastriatal injection was devoid of common systemic catalytic enzymes [28]. Lastly, miRNA copy number may be sparse in small EVs suggesting that merely overexpressing miRNA in the parent cell may require further optimization [116]. By addressing these challenges, including but not limited to increasing the understanding of inherent EV loading, and continuously exploring novel loading techniques, loading efficiency can be increased without corrupting the inherent benefits of EVs. Despite the numerous preclinical studies harnessing EVs as delivery vectors, each loading technique has its advantages and disadvantages and loading depends on a multitude of factors including donor cell choice, the type and modifications of the therapeutic cargos, and differences in disease states and target cells. Ultimately in order for the EV therapeutics to advance, researchers need to continuously develop and optimize platforms for the desired applications. With the early preclinical success, consistent improvement in loading since the initial attempts in the early 2010's, and progress into the clinic, EVs hold immense potential in becoming a next generation class of delivery vectors for therapeutic nucleic acids.

\section{CONCLUSION}

EV-based delivery of therapeutic nucleic acids is a promising approach to deliver new precision medicine treatments for various genetic diseases. As natural delivery vectors, EVs are highly advantageous. EVs advantages include, but not limited to their intrinsic ability to protect nucleic acid cargo, cross physiological barriers including the blood brain barrier, and are highly stable, with preclinical evidence suggestive of low toxicity and immunogenicity and increased circulation retention. These characteristics make them highly suitable for drug delivery purposes as seen in various preclinical models. Though there are a variety of loading mechanisms divided into two categories, pre and post isolation, loading must continuously be optimized to bridge the translational gap of EVs as delivery vectors. Overall, the nascent field of EV based delivery of nucleic acids has made immense progress and further studies will be required to support the preclinical findings to advance EVs through the clinic.

\section{Conflicts of interest}

The authors disclose no potential conflicts of interest.

\section{References}

[1] Setten RL, Rossi JJ, Han S ping (2019). The current state and future directions of RNAi-based therapeutics. Nat Rev Drug Discov, 18:421-446.

[2] Dammes N, Peer D (2020). Paving the Road for RNA Therapeutics. Trends Pharmacol Sci, 41:755-775.

[3] Sabitha KR, Shetty AK, Upadhya D (2021). Patientderived iPSC modeling of rare neurodevelopmental disorders: Molecular pathophysiology and prospective therapies. Neurosci Biobehav Rev, 121:201-219. 
[4] Bajan S, Hutvagner G (2020). RNA-Based Therapeutics: From Antisense Oligonucleotides to miRNAs. Cells, 9(1):137

[5] Kaczmarek JC, Kowalski PS, Anderson DG (2017). Advances in the delivery of RNA therapeutics: From concept to clinical reality. Genome Med. 9:60.

[6] Juliano RL (2016). The delivery of therapeutic oligonucleotides. Nucleic Acids Res, 44:6518-6548.

[7] Tatiparti K, Sau S, Kashaw SK, Iyer AK (2017). siRNA delivery strategies: A comprehensive review of recent developments. Nanomaterials. 17:4.

[8] Xue HY, Liu S, Wong HL (2014). Nanotoxicity: A key obstacle to clinical translation of sirna-based nanomedicine. Nanomedicine, 9:295-312.

[9] Gurav B, Srinivasan G (2017). Antisense oligonucleotides as therapeutics and their delivery. Curr Sci, 112:490-498.

[10] Johnsen KB, Gudbergsson JM, Skov MN, Pilgaard L, Moos T, Duroux M (2014). A comprehensive overview of exosomes as drug delivery vehicles - Endogenous nanocarriers for targeted cancer therapy. Biochim Biophys Acta - Rev Cancer, 1846:75-87.

[11] Gomari H, Moghadam MF, Soleimani M (2018). Targeted cancer therapy using engineered exosome as a natural drug delivery vehicle. Onco Targets Ther, 11:5753-5762.

[12] Zheng M, Huang M, Ma X, Chen H, Gao X (2019). Harnessing Exosomes for the Development of Brain Drug Delivery Systems. Bioconjug Chem, 30:9941005.

[13] Lai RC, Yeo RWY, Tan KH, Lim SK (2013). Exosomes for drug delivery - A novel application for the mesenchymal stem cell. Biotechnol Adv, 31:543551.

[14] Pinheiro A, Silva AM, Teixeira JH, Gonçalves RM, Almeida MI, Barbosa MA, et al. (2018). Extracellular vesicles: intelligent delivery strategies for therapeutic applications. J Control Release, 289:56-69.

[15] Ahmadzada T, Reid G, McKenzie DR (2018). Fundamentals of siRNA and miRNA therapeutics and a review of targeted nanoparticle delivery systems in breast cancer. Biophys Rev, 10:69-86.

[16] Magen I, Hornstein E (2014). Oligonucleotide-based therapy for neurodegenerative diseases. Brain Res, 1584:116-128.

[17] Wittrup A, Lieberman J (2015). Knocking down disease: A progress report on siRNA therapeutics. Nat Rev Genet, 16:543-552.

[18] Dana H, Chalbatani GM, Mahmoodzadeh H, Karimloo R, Rezaiean O, Moradzadeh A, et al. (2017). Molecular Mechanisms and Biological Functions of siRNA. Int $\mathrm{J}$ Biomed Sci, 13:48-57.

[19] O'Brien J, Hayder H, Zayed Y, Peng C (2018). Overview of microRNA biogenesis, mechanisms of actions, and circulation. Front Endocrinol (Lausanne). 9:402.

[20] Couto LB, High KA (2010). Viral vector-mediated RNA interference. Curr Opin Pharmacol, 10:534-542.

[21] Scoles DR, Minikel E V, Pulst SM (2019). Antisense oligonucleotides: A primer. Neurol Genet, 5(2):e323
[22] Sardone V, Zhou H, Muntoni F, Ferlini A, Falzarano MS (2017). Antisense oligonucleotide-based therapy for neuromuscular disease. Molecules. 22:4.

[23] Bishop KM (2017). Progress and promise of antisense oligonucleotide therapeutics for central nervous system diseases. Neuropharmacology, 120:56-62.

[24] Singh NN, Shishimorova M, Lu CC, Gangwani L, Singh RN (2009). A short antisense oligonucleotide masking a unique intronic motif prevents skipping of a critical exon in spinal muscular atrophy. RNA Biol, 6:341-350.

[25] Hua Y, Krainer AR (2012). Antisense-mediated exon inclusion. Methods Mol Biol, 867:307-323.

[26] Vickers TA, Koo S, Bennett CF, Crooke ST, Dean NM, Baker BF (2003). Efficient reduction of target RNAs by small interfering RNA and RNase H-dependent antisense agents. A comparative analysis. J Biol Chem, 278:7108-7118.

[27] Frazier KS (2015). Antisense Oligonucleotide Therapies:The Promise and the Challenges from a Toxicologic Pathologist's Perspective. Toxicol Pathol, 43:78-89.

[28] Didiot MC, Hall LM, Coles AH, Haraszti RA, Godinho BMDC, Chase K, et al. (2016). Exosome-mediated delivery of hydrophobically modified siRNA for huntingtin mRNA silencing. Mol Ther, 24:1836-1847.

[29] Usman WM, Pham TC, Kwok YY, Vu LT, Ma V, Peng $\mathrm{B}$, et al. (2018). Efficient RNA drug delivery using red blood cell extracellular vesicles. Nat Commun, 9:2359.

[30] Ohno SI, Takanashi M, Sudo K, Ueda S, Ishikawa A, Matsuyama N, et al. (2013). Systemically injected exosomes targeted to EGFR deliver antitumor microrna to breast cancer cells. Mol Ther, 21:185-191.

[31] Alvarez-Erviti L, Seow Y, Yin H, Betts C, Lakhal S, Wood MJA (2011). Delivery of siRNA to the mouse brain by systemic injection of targeted exosomes. Nat Biotechnol, 29:341-345.

[32] Shirley JL, de Jong YP, Terhorst C, Herzog RW (2020). Immune Responses to Viral Gene Therapy Vectors. Mol Ther, 28:709-722.

[33] Wang L, Li F, Dang L, Liang C, Wang C, He B, et al. (2016). In Vivo delivery systems for therapeutic genome editing. Int J Mol Sci. 22:4.

[34] Juliano RL, Carver K (2015). Cellular uptake and intracellular trafficking of oligonucleotides. Adv Drug Deliv Rev, 87:35-45.

[35] Chery J (2016). RNA therapeutics: RNAi and antisense mechanisms and clinical applications. Postdoc J. 4(7):35-50.

[36] Crooke ST, Wang S, Vickers TA, Shen W, Liang XH (2017). Cellular uptake and trafficking of antisense oligonucleotides. Nat Biotechnol, 35:230-237.

[37] Geary RS, Norris D, Yu R, Bennett CF (2015). Pharmacokinetics, biodistribution and cell uptake of antisense oligonucleotides. Adv Drug Deliv Rev, 87:46-51.

[38] Eckstein F (2014). Phosphorothioates, essential components of therapeutic oligonucleotides. Nucleic Acid Ther, 24:374-387.

[39] Nishina T, Numata J, Nishina K, Yoshida-Tanaka K, 
Nitta K, Piao W, et al. (2015). Chimeric antisense oligonucleotide conjugated to $\alpha$-Tocopherol. Mol Ther - Nucleic Acids, 4(1):e220

[40] Wang J, Lu Z, Wientjes MG, Au JLS (2010). Delivery of siRNA therapeutics: Barriers and carriers. AAPS J, 12:492-503.

[41] Nair JK, Willoughby JLS, Chan A, Charisse K, Alam MR, Wang Q, et al. (2014). Multivalent N acetylgalactosamine-conjugated siRNA localizes in hepatocytes and elicits robust RNAi-mediated gene silencing. J Am Chem Soc, 136:16958-16961.

[42] Hu B, Zhong L, Weng Y, Peng L, Huang Y, Zhao Y, et al. (2020). Therapeutic siRNA: state of the art. Signal Transduct Target Ther, 5:101

[43] Chernikov I V., Vlassov V V., Chernolovskaya EL (2019). Current development of siRNA bioconjugates: From research to the clinic. Front Pharmacol. 10:444 doi: 10.3389/fphar.2019.00444.

[44] Selvam C, Mutisya D, Prakash S, Ranganna K, Thilagavathi R (2017). Therapeutic potential of chemically modified siRNA: Recent trends. Chem Biol Drug Des, 90:665-678.

[45] Naso MF, Tomkowicz B, Perry WL, Strohl WR (2017). Adeno-Associated Virus (AAV) as a Vector for Gene Therapy. BioDrugs, 31:317-334.

[46] Stoica L, Sena-Esteves M (2016). Adeno associated viral vector delivered RNAi for gene therapy of SOD1 amyotrophic lateral sclerosis. Front Mol Neurosci. 9:56.

[47] Tomar RS, Matta H, Chaudhary PM (2003). Use of adeno-associated viral vector for delivery of small interfering RNA. Oncogene, 22:5712-5715.

[48] Colella P, Ronzitti G, Mingozzi F (2018). Emerging Issues in AAV-Mediated In Vivo Gene Therapy. Mol Ther - Methods Clin Dev, 8:87-104.

[49] Wang D, Tai PWL, Gao G (2019). Adeno-associated virus vector as a platform for gene therapy delivery. Nat Rev Drug Discov, 18:358-378.

[50] John Bunker DL (2014). Delivery Techniques in Gene Therapy: A Brief Overview. J Phys Chem Biophys, 4:3.

[51] Wang Y, Miao L, Satterlee A, Huang L (2015). Delivery of oligonucleotides with lipid nanoparticles. Adv Drug Deliv Rev, 87:68-80.

[52] Jackson LA, Anderson EJ, Rouphael NG, Roberts PC, Makhene M, Coler RN, et al. (2020). An mRNA Vaccine against SARS-CoV-2 — Preliminary Report. N Engl J Med, 383:1920-1931.

[53] Moss KH, Popova P, Hadrup SR, Astakhova K, Taskova M (2019). Lipid Nanoparticles for Delivery of Therapeutic RNA Oligonucleotides. Mol Pharm, 16:2265-2277.

[54] Schoenmaker L, Witzigmann D, Kulkarni JA, Verbeke R, Kersten G, Jiskoot W, et al. (2021). mRNA-lipid nanoparticle COVID-19 vaccines: Structure and stability. Int J Pharm, 601:120586.

[55] Sercombe L, Veerati T, Moheimani F, Wu SY, Sood AK, Hua S (2015). Advances and challenges of liposome assisted drug delivery. Front Pharmacol, 6:286.

[56] Mohamed M, Abu Lila AS, Shimizu T, Alaaeldin E,
Hussein A, Sarhan HA, et al. (2019). PEGylated liposomes: immunological responses. Sci Technol Adv Mater, 20:710-724.

[57] Verhoef JJF, Anchordoquy TJ (2013). Questioning the use of PEGylation for drug delivery. Drug Deliv Transl Res, 3:499-503.

[58] Simons M, Raposo G (2009). Exosomes--vesicular carriers for intercellular communication. Curr Opin Cell Biol, 21:575-581.

[59] Colombo M, Raposo G, Théry C (2014). Biogenesis, Secretion, and Intercellular Interactions of Exosomes and Other Extracellular Vesicles. Annu Rev Cell Dev Biol, 30:255-289.

[60] Raposo G, Stoorvogel W (2013). Extracellular vesicles: Exosomes, microvesicles, and friends. J Cell Biol, 200:373-383.

[61] O'Brien K, Breyne K, Ughetto S, Laurent LC, Breakefield XO (2020). RNA delivery by extracellular vesicles in mammalian cells and its applications. Nat Rev Mol Cell Biol, 21:585-606.

[62] Russell AE, Sneider A, Witwer KW, Bergese P, Bhattacharyya SN, Cocks A, et al. (2019). Biological membranes in EV biogenesis, stability, uptake, and cargo transfer: an ISEV position paper arising from the ISEV membranes and EVs workshop. J Extracell Vesicles, 21(10):585-606

[63] Valadi H, Ekström K, Bossios A, Sjöstrand M, Lee JJ, Lötvall JO (2007). Exosome-mediated transfer of mRNAs and microRNAs is a novel mechanism of genetic exchange between cells. Nat Cell Biol, 9:654659.

[64] Webb RL, Kaiser EE, Jurgielewicz BJ, Spellicy S, Scoville SL, Thompson TA, et al. (2018). Human Neural Stem Cell Extracellular Vesicles Improve Recovery in a Porcine Model of Ischemic Stroke. Stroke, 9:530-539.

[65] Webb RL, Kaiser EE, Scoville SL, Thompson TA, Fatima S, Pandya C, et al. (2018). Human Neural Stem Cell Extracellular Vesicles Improve Tissue and Functional Recovery in the Murine Thromboembolic Stroke Model. Transl Stroke Res, 9:530-539.

[66] Spellicy SE, Kaiser EE, Bowler MM, Jurgielewicz BJ, Webb RL, West FD, et al. (2020). Neural Stem Cell Extracellular Vesicles Disrupt Midline Shift Predictive Outcomes in Porcine Ischemic Stroke Model. Transl Stroke Res, 11:776-788.

[67] Huang L, Ma W, Ma Y, Feng D, Chen H, Cai B (2015). Exosomes in mesenchymal stem cells, a new therapeutic strategy for cardiovascular diseases? Int J Biol Sci, 11:238-245.

[68] Zhang Y, Liu Y, Liu H, Tang WH (2019). Exosomes: Biogenesis, biologic function and clinical potential. Cell Biosci, 9(19).

[69] Yue B, Yang H, Wang J, Ru W, Wu J, Huang Y, et al. (2020). Exosome biogenesis, secretion and function of exosomal miRNAs in skeletal muscle myogenesis. Cell Prolif. doi: 10.1111/cpr.12857.

[70] Keller S, Sanderson MP, Stoeck A, Altevogt P (2006). Exosomes: From biogenesis and secretion to biological function. Immunol Lett, 107:102-108. 
[71] Colombo M, Moita C, van Niel G, Kowal J, Vigneron J, Benaroch P, et al. (2013). Analysis of ESCRT functions in exosome biogenesis, composition and secretion highlights the heterogeneity of extracellular vesicles. J Cell Sci, 126:5553-65.

[72] Sterzenbach U, Putz U, Low LH, Silke J, Tan SS, Howitt J (2017). Engineered Exosomes as Vehicles for Biologically Active Proteins. Mol Ther, 25:1269-1278.

[73] Villarroya-Beltri C, Baixauli F, Gutiérrez-Vázquez C, Sánchez-Madrid F, Mittelbrunn M (2014). Sorting it out: Regulation of exosome loading. Semin Cancer Biol, 28:3-13.

[74] Abels ER, Breakefield XO (2016). Introduction to Extracellular Vesicles: Biogenesis, RNA Cargo Selection, Content, Release, and Uptake. Cell Mol Neurobiol, 36:301-312.

[75] Kamerkar S, Lebleu VS, Sugimoto H, Yang S, Ruivo CF, Melo SA, et al. (2017). Exosomes facilitate therapeutic targeting of oncogenic KRAS in pancreatic cancer. Nature, 546:498-503.

[76] Sancho-Albero M, Navascués N, Mendoza G, Sebastián V, Arruebo M, Martín-Duque P, et al. (2019). Exosome origin determines cell targeting and the transfer of therapeutic nanoparticles towards target cells. J Nanobiotechnology. 17:16.

[77] Murphy DE, de Jong OG, Brouwer M, Wood MJ, Lavieu G, Schiffelers RM, et al. (2019). Extracellular vesicle-based therapeutics: natural versus engineered targeting and trafficking. Exp Mol Med. 51:1-12.

[78] Jurgielewicz B, Yao Y, Stice S (2020). Kinetics and Specificity of HEK293T Extracellular Vesicle Uptake using Imaging Flow Cytometry. Nanoscale Res Lett. 15:170.

[79] Wiklander OPB, Nordin JZ, O'Loughlin A, Gustafsson Y, Corso G, Mäger I, et al. (2015). Extracellular vesicle in vivo biodistribution is determined by cell source, route of administration and targeting. $\mathrm{J}$ Extracell vesicles, 4:26316.

[80] Yang J, Zhang X, Chen X, Wang L, Yang G (2017). Exosome Mediated Delivery of miR-124 Promotes Neurogenesis after Ischemia. Mol Ther - Nucleic Acids, 7:278-287.

[81] Liang Y, Duan L, Lu J, Xia J (2021). Engineering exosomes for targeted drug delivery. Theranostics, 11:3183-3195.

[82] De Jong OG, Kooijmans SAA, Murphy DE, Jiang L, Evers MJW, Sluijter JPG, et al. (2019). Drug Delivery with Extracellular Vesicles: From Imagination to Innovation. Acc Chem Res, 52:1761-1770.

[83] Pardridge WM (2012). Drug transport across the bloodbrain barrier. J Cereb Blood Flow Metab, 32:19591972.

[84] Chen CC, Liu L, Ma F, Wong CW, Guo XE, Chacko J V., et al. (2016). Elucidation of Exosome Migration Across the Blood-Brain Barrier Model In Vitro. Cell Mol Bioeng, 9:509-529.

[85] Saint-Pol J, Gosselet F, Duban-Deweer S, Pottiez G, Karamanos Y (2020). Targeting and Crossing the Blood-Brain Barrier with Extracellular Vesicles. Cells. 9:851.
[86] Ye Z, Zhang T, He W, Jin H, Liu C, Yang Z, et al. (2018). Methotrexate-Loaded Extracellular Vesicles Functionalized with Therapeutic and Targeted Peptides for the Treatment of Glioblastoma Multiforme. ACS Appl Mater Interfaces, 10:12341-12350.

[87] Mulcahy LA, Pink RC, Raul D, Carter F, David D, Carter RF (2014). Routes and mechanisms of extracellular vesicle uptake. J Extracell Vesicles, 4:3.

[88] Horibe S, Tanahashi T, Kawauchi S, Murakami Y, Rikitake Y (2018). Mechanism of recipient celldependent differences in exosome uptake. BMC Cancer. doi: 10.1186/s12885-017-3958-1.

[89] McKelvey KJ, Powell KL, Ashton AW, Morris JM, McCracken SA (2015). Exosomes: Mechanisms of Uptake. J Circ biomarkers, 4:7.

[90] Millard M, Yakavetsa I, Piffoux M, Brun A, Gazeau F, Guigner JM, et al. (2018). mTHPC-loaded extracellular vesicles outperform liposomal and free mTHPC formulations by an increased stability drug delivery efficiency and cytotoxic effect in tridimensional model of tumors. Drug Deliv, 25:1790-1801.

[91] Joshi BS, de Beer MA, Giepmans BNG, Zuhorn IS (2020). Endocytosis of Extracellular Vesicles and Release of Their Cargo from Endosomes. ACS Nano, 14:4444-4455.

[92] Sancho-Albero M, Rubio-Ruiz B, Pérez-López AM, Sebastián V, Martín-Duque P, Arruebo M, et al. (2019). Cancer-derived exosomes loaded with ultrathin palladium nanosheets for targeted bioorthogonal catalysis. Nat Catal, 2:864-872.

[93] Zhou Y, Zhou G, Tian C, Jiang W, Jin L, Zhang C, et al. (2016). Exosome-mediated small RNA delivery for gene therapy. Wiley Interdiscip Rev RNA, 7:758-771.

[94] Zhu X, Badawi M, Pomeroy S, Sutaria DS, Xie Z, Baek A, et al. (2017). Comprehensive toxicity and immunogenicity studies reveal minimal effects in mice following sustained dosing of extracellular vesicles derived from HEK293T cells. J Extracell Vesicles, 6(1): 1324730

[95] Guo Y, Ji X, Liu J, Fan D, Zhou Q, Chen C, et al. (2019). Effects of exosomes on pre-metastatic niche formation in tumors. Mol Cancer. 18:39.

[96] Saleh AF, Lázaro-Ibáñez E, Forsgard MAM, Shatnyeva O, Osteikoetxea X, Karlsson F, et al. (2019). Extracellular vesicles induce minimal hepatotoxicity and immunogenicity. Nanoscale, 11:6990-7001.

[97] Vogel A, Upadhya R, Shetty AK (2018). Neural stem cell derived extracellular vesicles: Attributes and prospects for treating neurodegenerative disorders. EBioMedicine, 38:273-282.

[98] Lapchak PA, Boitano PD, de Couto G, Marbán E (2018). Intravenous xenogeneic human cardiospherederived cell extracellular vesicles (exosomes) improves behavioral function in small-clot embolized rabbits. Exp Neurol, 307:109-117.

[99] Otero-Ortega L, Laso-García F, Del Carmen GómezDe Frutos M, Rodríguez-Frutos B, Pascual-Guerra J, Fuentes B, et al. (2017). White matter repair after extracellular vesicles administration in an experimental animal model of subcortical stroke. Sci Rep. 7:44433 
doi: $10.1038 /$ srep44433.

[100] Xin H, Katakowski M, Wang F, Qian JY, Liu XS, Ali $\mathrm{MM}$, et al. (2017). MicroRNA cluster miR-17-92 Cluster in Exosomes Enhance Neuroplasticity and Functional Recovery after Stroke in Rats. Stroke, 48:747-753.

[101] Mathiyalagan P, Liang Y, Kim D, Misener S, Thorne T, Kamide CE, et al. (2017). Angiogenic Mechanisms of Human CD34+ Stem Cell Exosomes in the Repair of Ischemic Hindlimb. Circ Res, 120:1466-1476.

[102] Wang X, Chen Y, Zhao Z, Meng Q, Yu Y, Sun J, et al. (2018). Engineered exosomes with ischemic myocardium-targeting peptide for targeted therapy in myocardial infarction. J Am Heart Assoc. 7:15.

[103] Yamashita T, Takahashi Y, Takakura Y (2018). Possibility of Exosome-Based Therapeutics and Challenges in Production of Exosomes Eligible for Therapeutic Application. Biol Pharm Bull, 41:835-842.

[104] Anderson JD, Johansson HJ, Graham CS, Vesterlund M, Pham MT, Bramlett CS, et al. (2016). Comprehensive proteomic analysis of mesenchymal stem cell exosomes reveals modulation of angiogenesis via nuclear factor-kappaB signaling. Stem Cells, 34:601-613.

[105] Upadhya D, Shetty AK (2019). Promise of extracellular vesicles for diagnosis and treatment of epilepsy. Epilepsy Behav. doi: 10.1016/j.yebeh.2019.106499.

[106] Upadhya D, Shetty AK (2019). Extracellular Vesicles as Therapeutics for Brain Injury and Disease. Curr Pharm Des, 25:3500-3505.

[107] Longa Q, Upadhya D, Hattiangady B, Kim DK, An SY, Shuai B, et al. (2017). Intranasal MSC-derived A1exosomes ease inflammation, and prevent abnormal neurogenesis and memory dysfunction after status epilepticus. Proc Natl Acad Sci U S A, 114:E3536E3545.

[108] Janas T, Janas MM, Sapoń K, Janas T (2015). Mechanisms of RNA loading into exosomes. FEBS Lett, 589:1391-1398.

[109] Lee S-T, Im W, Ban J-J, Lee M, Jung K-H, Lee SK, et al. (2017). Exosome-Based Delivery of miR-124 in a Huntington's Disease Model. J Mov Disord, 10:45-52.

[110] Mizrak A, Bolukbasi MF, Ozdener GB, Brenner GJ, Madlener S, Erkan EP, et al. (2013). Genetically engineered microvesicles carrying suicide mRNA/protein inhibit schwannoma tumor growth. Mol Ther, 21:101-108.

[111] Xin H, Li Y, Buller B, Katakowski M, Zhang Y, Wang $X$, et al. (2012). Exosome-mediated transfer of miR$133 \mathrm{~b}$ from multipotent mesenchymal stromal cells to neural cells contributes to neurite outgrowth. Stem Cells, 30:1556-1564.

[112] Zhang Y, Li L, Yu J, Zhu D, Zhang Y, Li X, et al. (2014). Microvesicle-mediated delivery of transforming growth factor $\beta 1$ siRNA for the suppression of tumor growth in mice. Biomaterials, 35:4390-4400.

[113] Kanada M, Bachmann MH, Hardy JW, Frimannson DO, Bronsart L, Wang A, et al. (2015). Differential fates of biomolecules delivered to target cells via extracellular vesicles. Proc Natl Acad Sci U S A, E1433-E1442.

[114] Jiang L, Vader P, Schiffelers RM (2017). Extracellular vesicles for nucleic acid delivery: Progress and prospects for safe RNA-based gene therapy. Gene Ther, 24:157-166.

[115] Yang Z, Shi J, Xie J, Wang Y, Sun J, Liu T, et al. (2020). Large-scale generation of functional mRNAencapsulating exosomes via cellular nanoporation. Nat Biomed Eng, 4:69-83.

[116] Reshke R, Taylor JA, Savard A, Guo H, Rhym LH, Kowalski PS, et al. (2020). Reduction of the therapeutic dose of silencing RNA by packaging it in extracellular vesicles via a pre-microRNA backbone. Nat Biomed Eng, 4:52-68.

[117] Kojima R, Bojar D, Rizzi G, Hamri GC El, El-Baba MD, Saxena P, et al. (2018). Designer exosomes produced by implanted cells intracerebrally deliver therapeutic cargo for Parkinson's disease treatment. Nat Commun. 9:1305.

[118] Hung ME, Leonard JN (2016). A platform for actively loading cargo RNA to elucidate limiting steps in EVmediated delivery. J Extracell Vesicles, 5:31027.

[119] Sutaria DS, Jiang J, Elgamal OA, Pomeroy SM, Badawi M, Zhu X, et al. (2017). Low active loading of cargo into engineered extracellular vesicles results in inefficient miRNA mimic delivery. $\mathrm{J}$ Extracell Vesicles, 6:1333882.

[120] György B, Sage C, Indzhykulian AA, Scheffer DI, Brisson AR, Tan S, et al. (2017). Rescue of Hearing by Gene Delivery to Inner-Ear Hair Cells Using ExosomeAssociated AAV. Mol Ther, 25:379-391.

[121] Aqil F, Munagala R, Jeyabalan J, Agrawal AK, Kyakulaga AH, Wilcher SA, et al. (2019). Milk exosomes - Natural nanoparticles for siRNA delivery. Cancer Lett, 449:186-195.

[122] Cooper JM, Wiklander PBO, Nordin JZ, Al-Shawi R, Wood MJ, Vithlani M, et al. (2014). Systemic exosomal siRNA delivery reduced alpha-synuclein aggregates in brains of transgenic mice. Mov Disord, 29:1476-85.

[123] Kase Y, Uzawa K, Wagai S, Yoshimura S, Yamamoto JI, Toeda Y, et al. (2021). Engineered exosomes delivering specific tumor-suppressive RNAi attenuate oral cancer progression. Sci Rep. 11:5897.

[124] Nasiri Kenari A, Cheng L, Hill AF (2020). Methods for loading therapeutics into extracellular vesicles and generating extracellular vesicles mimetic-nanovesicles. Methods, 177:103-113.

[125] Jhan YY, Prasca-Chamorro D, Palou Zuniga G, Moore DM, Arun Kumar S, Gaharwar AK, et al. (2020). Engineered extracellular vesicles with synthetic lipids via membrane fusion to establish efficient gene delivery. Int J Pharm, 573:118802.

[126] Lamichhane TN, Raiker RS, Jay SM (2015). Exogenous DNA loading into extracellular vesicles via electroporation is size-dependent and enables limited gene delivery. Mol Pharm, 12:3650-3657.

[127] Kooijmans SAA, Stremersch S, Braeckmans K, De Smedt SC, Hendrix A, Wood MJA, et al. (2013). Electroporation-induced siRNA precipitation obscures 
the efficiency of siRNA loading into extracellular vesicles. J Control Release, 172:229-238.

[128] Johnsen KB, Gudbergsson JM, Skov MN, Christiansen G, Gurevich L, Moos T, et al. (2016). Evaluation of electroporation-induced adverse effects on adiposederived stem cell exosomes. Cytotechnology, 68:21252138.

[129] Pomatto MAC, Bussolati B, D'Antico S, Ghiotto S, Tetta C, Brizzi MF, et al. (2019). Improved Loading of Plasma-Derived Extracellular Vesicles to Encapsulate Antitumor miRNAs. Mol Ther - Methods Clin Dev, 13:133-144.

[130] Haney MJ, Klyachko NL, Zhao Y, Gupta R, Plotnikova EG, He Z, et al. (2015). Exosomes as drug delivery vehicles for Parkinson's disease therapy. J Control Release, 207:18-30.

[131] Lamichhane TN, Jeyaram A, Patel DB, Parajuli B, Livingston NK, Arumugasaamy N, et al. (2016). Oncogene Knockdown via Active Loading of Small RNAs into Extracellular Vesicles by Sonication. Cell Mol Bioeng, 9:315-324.

[132] Shtam TA, Kovalev RA, Varfolomeeva EY, Makarov EM, Kil Y V., Filatov M V. (2013). Exosomes are natural carriers of exogenous siRNA to human cells in vitro. Cell Commun Signal, 11:88.

[133] Lin Y, Wu J, Gu W, Huang Y, Tong Z, Huang L, et al. (2018). Exosome-Liposome Hybrid Nanoparticles Deliver CRISPR/Cas9 System in MSCs. Adv Sci, 5:1700611.

[134] Yang T, Fogarty B, LaForge B, Aziz S, Pham T, Lai L, et al. (2017). Delivery of Small Interfering RNA to Inhibit Vascular Endothelial Growth Factor in Zebrafish Using Natural Brain Endothelia CellSecreted Exosome Nanovesicles for the Treatment of Brain Cancer. AAPS J, 19:475-486.

[135] Lin Y, Wu J, Gu W, Huang Y, Tong Z, Huang L, et al. (2018). Exosome-Liposome Hybrid Nanoparticles Deliver CRISPR/Cas9 System in MSCs. Adv Sci, 5:1700611.

[136] Haraszti R, Coles A, Aronin N, Khvorova A, Didiot MC (2017). Loading of Extracellular Vesicles with Chemically Stabilized Hydrophobic siRNAs for the Treatment of Disease in the Central Nervous System. BIO-PROTOCOL, 7(20):e2338.

[137] Biscans A, Haraszti RA, Echeverria D, Miller R, Didiot MC, Nikan M, et al. (2018). Hydrophobicity of LipidConjugated siRNAs Predicts Productive Loading to Small Extracellular Vesicles. Mol Ther, 26:1520-1528.

[138] Alterman JF, Hall LM, Coles AH, Hassler MR, Didiot MC, Chase K, et al. (2015). Hydrophobically Modified siRNAs Silence Huntingtin mRNA in Primary Neurons and Mouse Brain. Mol Ther - Nucleic Acids, 4(12):e266.

[139] Stremersch S, Vandenbroucke RE, Van Wonterghem E, Hendrix A, De Smedt SC, Raemdonck K (2016). Comparing exosome-like vesicles with liposomes for the functional cellular delivery of small RNAs. J Control Release, 51-61.

[140] Haraszti RA, Miller R, Didiot MC, Biscans A, Alterman JF, Hassler MR, et al. (2018). Optimized
Cholesterol-siRNA Chemistry Improves Productive Loading onto Extracellular Vesicles. Mol Ther, 26:1973-1982.

[141] Gao X, Ran N, Dong X, Zuo B, Yang R, Zhou Q, et al. (2018). Anchor peptide captures, targets, and loads exosomes of diverse origins for diagnostics and therapy. Sci Transl Med, 10:195.

[142] Jang SC, Economides KD, Moniz RJ, Sia CL, Lewis N, McCoy C, et al. (2021). ExoSTING, an extracellular vesicle loaded with STING agonists, promotes tumor immune surveillance. Commun Biol, 4(1):497.

[143] Codiak Reports Positive Initial Phase 1 Results for. www.globenewswire.com/news-release/2020/12/30/ 2151648/0/en/Codiak-Reports-Positive-Initial-Phase1-Results-for-exoIL-12-Demonstrating-Tolerabilityand-Absence-of-Systemic-IL-12-Exposure-inHealthy-Volunteers.html. Accessed 12 Jun 2021.

[144] Chen YS, Lin EY, Chiou TW, Harn HJ (2020). Exosomes in clinical trial and their production in compliance with good manufacturing practice. Tzu Chi Med J, 32:113-120.

[145] Cully M (2021). Exosome-based candidates move into the clinic. Nat Rev Drug Discov, 20:6-7.

[146] Lener T, Gioma M, Aigner L, Börger V, Buzas E, Camussi G, et al. (2015). Applying extracellular vesicles based therapeutics in clinical trials - an ISEV position paper. J Extracell Vesicles, 4:1-31.

[147] Théry C, Witwer KW, Aikawa E, Alcaraz MJ, Anderson JD, Andriantsitohaina R, et al. (2018). Minimal information for studies of extracellular vesicles 2018 (MISEV2018): a position statement of the International Society for Extracellular Vesicles and update of the MISEV2014 guidelines. J Extracell Vesicles, 7(1): 1535750.

[148] Jiang XC, Gao JQ (2017). Exosomes as novel biocarriers for gene and drug delivery. Int $\mathrm{J}$ Pharm, 521:167-175.

[149] Konoshenko MY, Lekchnov EA, Vlassov A V, Laktionov PP (2018). Isolation of Extracellular Vesicles: General Methodologies and Latest Trends. Biomed Res Int. 2018:854347.

[150] Willis GR, Kourembanas S, Mitsialis SA (2017). Toward Exosome-Based Therapeutics: Isolation, Heterogeneity, and Fit-for-Purpose Potency. Front Cardiovasc Med, 4:63.

[151] Ludwig N, Whiteside TL, Reichert TE (2019). Challenges in exosome isolation and analysis in health and disease. Int J Mol Sci. doi: 10.3390/ijms20194684.

[152] Zhou Y, Zhou G, Tian C, Jiang W, Jin L, Zhang C, et al. (2016). Exosome-mediated small RNA delivery for gene therapy. Wiley Interdiscip Rev RNA, 7:758-771.

[153] Liu, Y., Li, D., Liu, Z. et al. (2015) Targeted exosomemediated delivery of opioid receptor $\mathrm{Mu}$ siRNA for the treatment of morphine relapse. Sci Rep 5: 17543. 